\title{
Iron Production in North Pare, Tanzania: Archaeometallurgical and Geoarchaeological Perspectives on Landscape Change
}

\author{
L. Iles (i) • D. Stump • M. Heckmann • C. Lang • \\ P. J. Lane
}

Published online: 12 September 2018

(C) The Author(s) 2018

\begin{abstract}
Archaeology, archaeometallurgy and geoarchaeology are combined in this research to examine the chronology and development of iron metallurgy and its environmental repercussions in North Pare, Tanzania. Pare was a prominent centre for iron production from at least the second half of the first millennium AD, and it has been assumed that this technology - with its demand for wood charcoal - had a significant and detrimental effect on local forest cover. This research sought to examine this claim by exploring the spatial, chronological and technological characteristics of iron production in Pare in conjunction with geoarchaeological evidence. Contrary to older assumptions, our results demonstrate that erosion processes
\end{abstract}

\author{
L. Iles $(\bowtie)$ \\ Department of Archaeology, University of Sheffield, Sheffield, \\ UK \\ e-mail: 1.iles@sheffield.ac.uk \\ D. Stump · C. Lang \\ Department of Archaeology, University of York, York, UK
}

\section{Heckmann}

Bundesanstalt für Geowissenschaften und Rohstoffe, Hanover, Germany

\section{P. J. Lane}

Department of Archaeology and Ancient History, Uppsala University, Uppsala, Sweden

\section{P. J. Lane}

Honorary Research Fellow, School of Geography, Archaeology and Environmental Studies, University of the Witwatersrand, Johannesburg, South Africa were well established in North Pare before the documented intensification of smelting and smithing activity, and that iron production continued despite environmental changes. We suggest that although iron production may well have contributed to deforestation and erosion in Pare, it is unlikely to be the sole causal factor.

Résumé L'archéologie, l'archéométallurgie et la géoarchéologie sont combinées dans cette recherche pour examiner la chronologie et le développement de la métallurgie du fer et ses répercussions sur l'environnement à North Pare, en Tanzanie. Pare était un centre important pour la production de fer depuis au moins la seconde moitié du premier millénaire après JC, et on a supposé que cette industrie - avec sa demande de charbon de bois - avait un effet significatif et nuisible sur le couvert forestier local. Cette recherche a cherché à examiner cette revendication en explorant les caractéristiques spatiales, chronologiques et technologiques de la production de fer à Pare en conjonction avec des preuves géoarchéologiques. Contrairement à des hypothèses plus anciennes, nos résultats démontrent que les processus d'érosion étaient bien établis à North Pare avant l'intensification documentée de l'activité de fonderie et de forge, et que la production de fer continuait malgré les changements environnementaux. Nous suggérons que, bien que la production de fer ait pu contribuer à la déforestation et à l'érosion à Pare, il est. peu probable qu'elle soit le seul facteur causal.

Keywords Tanzania · East Africa · Iron Age · Metallurgy $\cdot$ Iron smelting $\cdot$ Historical ecology 


\section{Introduction}

This paper presents the results of combined archaeological, archaeometallurgical and geoarchaeological research on the chronology and development of iron metallurgy and its possible environmental consequences in North Pare, northern Tanzania (Fig. 1). This is an area that is renowned historically for its iron production, yet which has remained relatively under-examined from an archaeological perspective despite promising early studies. Since 2009 when this research was initiated, several phases of field survey and excavation, alongside geoarchaeological research and laboratory-based archaeometallurgical analyses, have been completed. The aims of this research have evolved over time but, in essence, the primary objectives have been as follows:

- To establish the spatial distribution of iron production and processing sites across North Pare.

- To establish the chronology of iron smelting in the Pare region and the date of the different archaeological traces of iron processing encountered during archaeological survey.

- To reconstruct through archaeometallurgical analysis the technological processes involved.

- To determine the environmental consequences of iron metallurgy for the Pare landscape, and in particular to assess the hypothesis that local precolonial iron industries were a primary contributor to the stimulation of enhanced soil erosion in North Pare.

Historical and Ethnographic Perspectives on Iron Production in Pare

Oral and documentary historical sources spanning the sixteenth to early twentieth centuries AD assert that Pare was a significant iron producer in the region of northern Tanzania in the recent past. The Pare mountains contained all the resources - high-quality ore, clay and fuel - needed to make iron. Furthermore, not only was there a local market for iron in Pare itself, the wider region was "heavily dependent on the Pare smelters" (Kimambo 1996, p. 82; see also Maghimbi 1994), particularly the agricultural areas of Usambara and Kilimanjaro where the raw materials required for iron production were less plentiful. This economic stimulus brought prosperity to the Pare region and provided the basis for the political power of Pare clans that controlled iron production (Holy 1957, pp. 355, 367; Stahl 1964, p. 293; Kimambo 1968, p. 25, 1996, p. 82; Sheridan 2001).

European travellers to the region in the nineteenth and twentieth centuries emphasised the intensity of iron production in Pare at the time. It was a thriving industry exploiting a ready supply of magnetite, present as ore sands in stream-beds derived from the decomposition of iron-mica gneiss ubiquitous in the Pare hills (Kersten 1869, p. 19; Baumann 1891, p. 232; Meyer 1891, p. 224). When von der Decken planned his 1862 expedition to Tanzania, he explicitly hoped to visit "the iron country of Usangi" (Kersten 1869, p. 2), and was amazed at the furnaces that filled the Butu area in North Pare's eastern foothills (Fig. 1): "Das also sind die flammenden und rauchenden Oefen, welche uns beim Betreten des Usanga gebietes in Erstaunen gesetzt hatten!" (Kersten 1869, p. 19). The Austrian explorer Oscar Baumann was similarly struck by Pare's iron industry in 1890, noting that smelting was concentrated around Vudee in South Pare, and Usangi and Ugweno in North Pare. The small smelting furnaces he saw were protected from the elements with a basic canopied roof - the ore sand was emptied into a furnace pit, covered with charcoal, and fired; air was pumped into the furnace through a single metre-long tuyère fed by a pair of bowl bellows (Baumann 1891, p. 233), similar in description to those observed a few decades earlier by von der Decken (Kersten 1869) around Usangi. Eleven litres of this iron-rich sand reportedly produced typically six small blooms, which in 1910 were of equivalent value to one goat (Holy 1957, p. 353). The German missionary Kotz (1922, pp. 138-140), on the other hand, described an unusual stone-built furnace "not even sealed in the joints and cracks with clay" standing c. $30 \mathrm{~cm}$ high, and with a $1-1.5 \mathrm{~m}$ long tuyère providing an air supply, whereas Meyer described "a rude sort of earthen furnace, in which the melted metal [probably meaning molten slag] gradually falls to the bottom" (Meyer 1891, p. 224).

Impressed by the extensive industry they saw, these European observers also noted their impressions of North Pare's environment, particularly regarding tree cover, yet refrained from linking the two:

Anything approaching a forest is only to be met with in the uninhabited district in the north-west, along the mountains on the outskirts of the region, on the side facing the plains. Elsewhere everything has been burned down for clearings, or, as 


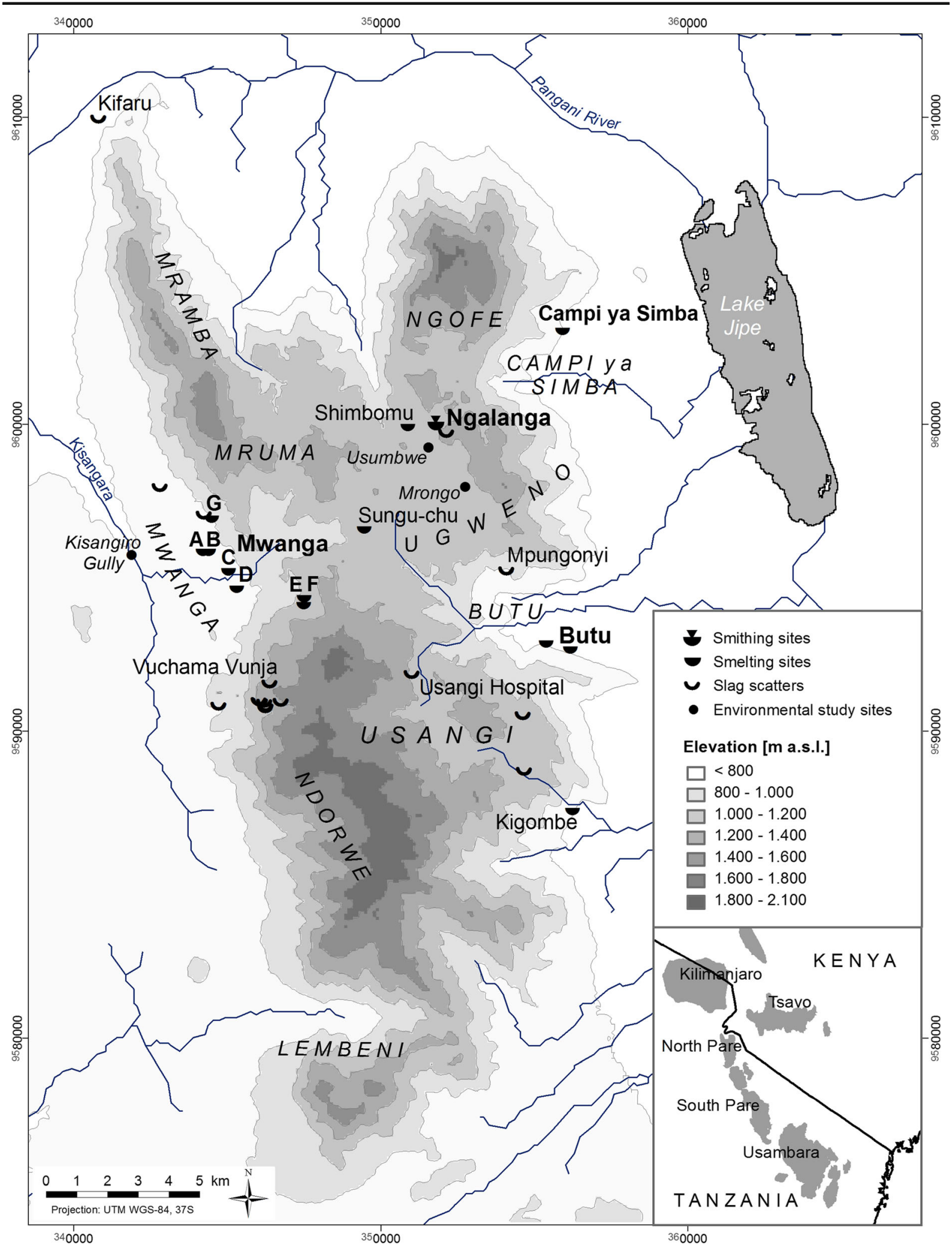

Fig. 1 North Pare: major towns and sites mentioned in the text (images in full colour online) 
on the higher zones of the mountains, the slopes are covered with low bush, grass, or ferns. (Meyer 1891, p. 223)

Baumann (1891, p. 200) described a similar highland scene dominated by ferns, grasses and heather, and interpreted pockets of woodland within cultivated areas as remnants of an earlier, more extensive forest. The clearance of this forest, as elsewhere in the northern Eastern Arc mountains (e.g., Kaoneka and Solberg 1994, pp. 210-211; Newmark 1998, p. 29), has been linked to increased soil erosion (Mbaga-Semgalawe and Folmer 2000, pp. 222-223). In later narratives, this deforestation has been explicitly attributed to Pare's iron industries: "by the second half of the nineteenth century, North Pare had been largely denuded of trees to fuel the furnaces that supplied iron to the whole region" (Håkansson 2008a, p. 246).

Throughout the Pare region, economic activity was semi-specialised into cultivation, pastoralism and craft industries (Håkansson 2008a, pp. 246, 255). Even within the iron production sequence itself, different clan lineages operated independently to undertake the distinct technologies of smelting (producing iron from an ore), smithing (working iron into a useable object) and charcoal production (Kimambo 1968, 1996; Sutton 1972; Sheridan 2001). North Pare smelters of the Wafinanga lineage worked in the lowlands - where fuel and clay were more readily available (Sheridan 2001, p. 111) - to produce raw "blooms" of iron fused with charcoal and slag. These unworked blooms were exchanged informally for livestock or agricultural produce, traded outside of Pare (see Håkansson 2008b, Fig. 3) or sold in local markets (Maghimbi 1994; Sheridan 2001), which were generally situated along the middle of the mountain range, linking the economies of the western and eastern slopes (Håkansson 2008b). Granite outcrops at Mruma market in Ugweno are pockmarked with small hollows - still visible today — once used to break up pieces of bloomery iron to use as small change in payment for market items (Fosbrooke 1954). Via these means, iron was transported up into the highlands from the smelting sites following the irira (pathways, Fig. 2a-c) that were used to move cattle between lowland grazing and highland agricultural zones (Sheridan 2001, p. 136), where it was in turn worked by Wanyindo blacksmiths (Kimambo 1996; also Sutton 1972; Maghimbi 1994). A third lineage-the Wakamoto-provided charcoal to both smiths and smelters (Sheridan 2001, p. 111).
Of particular interest given the oft-cited male-dominated nature of smelting in sub-Saharan Africa, both Baumann (1891, p. 233) and Kotz (1922, p. 138) describe smelting in North Pare as women's work, with Baumann's statement accompanied by a sketch of a Pare woman pumping the bellows of a furnace. Women are also reported to have had a prominent role in panning for iron-rich, magnetite sand from streams, first picking black sand from the stream bed and then cleaning it on the adjacent banks by flushing away the lighter clay particles (Holy 1957, p. 277; M. Sheridan pers. comm. 2018). It is possible that this gendered division of labour reflects changing modes of wealth accumulation from the end of the nineteenth century (Sheridan 2001, p. 112), though there are other examples - albeit rare - of women's participation in iron metallurgy in other African regions (Chirikure 2007; Iles 2013; Mtetwa et al. 2017).

As noted above, the ethnographic observations and informant accounts also suggest a degree of variation in smelting technologies used, that included both flat and sunken "fire-pits", either using multiple tuyères (M. Sheridan pers. comm. 2018) or a single tuyère c. 1.0$1.5 \mathrm{~m}$ long leading to a pair of goat-skin bellows similar to examples collected in the early twentieth century by the German missionary Hans August Fuchs, and now in Náprstek Museum in Prague (Jiroušková 2010; Fig. 3a). As Holy (1957, p. 279, 1959) noted, Kotz may have been describing a later phase in the history of iron production in Pare which, although still active in some areas in the early 1900 s, had reduced dramatically compared with a few decades earlier. This was due to the influx of readily available scrap metal that accompanied the nearby construction of the Usambara Railway, and the establishment in Pare trading centres of shops, mostly Indian-owned, selling imported iron and steel tools (Fosbrooke 1954; Illife 1979, p. 135; Maghimbi 1994; Sheridan 2001, p. 223). Local smithing crafts, however, continued, and ethnographic collections made in the early twentieth century indicated that wooden handled and handle-less iron hammers, iron tongs and simple stone anvils were the basic tools of the trade (Holy 1958, 1959; Jiroušková 2010; Fig. 3b-d).

Previous Archaeological Research

Archaeological surveys from the 1960s onwards confirmed that Pare was indeed an active centre for iron production since at least the second half of the first 

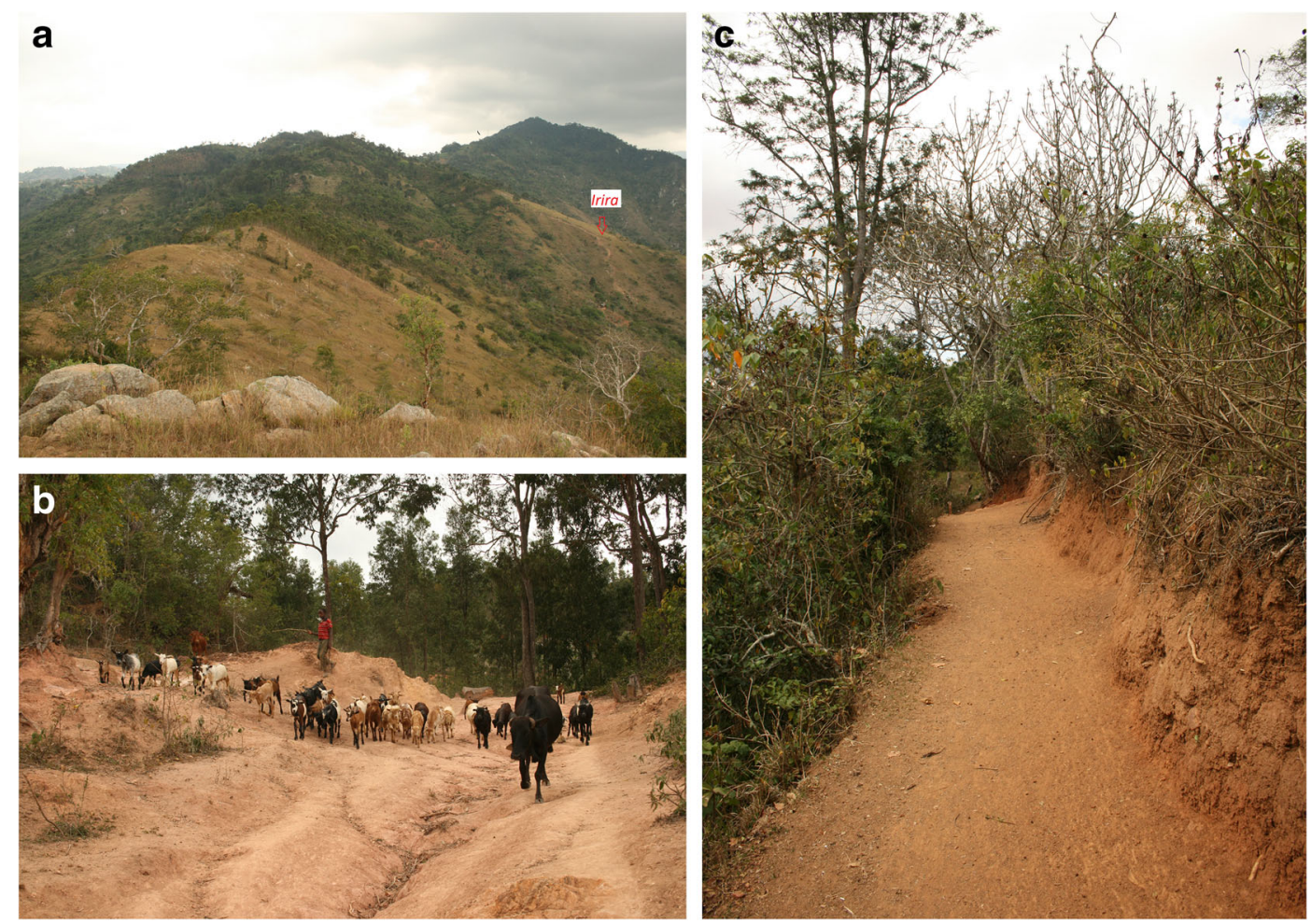

Fig. 2 a Irira leading to northern Pare foothills near Butu. b Livestock descending an irira pathway in Ugweno. c A well-used irira in Ugweno. (photos: P. Lane, July 2009)

millennium AD. The earliest dates associated with iron smelting in the region derive from just south of the Pare range. Systematic survey of the Usambara mountains in the 1980s found a number of Early Iron Age (EIA) sites on the uppermost slopes of these hills (Schmidt 1988, 1989), including an iron smelting furnace at Nkese, dated to between the second and third centuries AD (Schmidt 1988, p. 36), with similarities to EIA "brick" furnaces of northwest Tanzania, Rwanda and Burundi (cf. Raymaekers and Noten 1986). An earlier survey of archaeological sites in South Pare and Usambara (Soper 1967) had found approximately 80 sites - several of which were associated with iron smelting - particularly in the foothills and upland areas, with smelting remains much more frequent in South Pare compared to Usambara. Two small smelting furnaces at Kasapo in the western foothills of South Pare were c. $50 \mathrm{~cm}$ in diameter and lined with baked clay (Soper 1967, p. 29; Fig. 4).

A more recent survey along the Pangani basin included survey areas to the southwest of the Usambara Mountains and the east of South Pare (Walz 2010, 2017). Surface finds - primarily comprising pottery and glass beads - dated the majority of the newly located archaeological sites to the last 1500 years, 24 of which bore evidence for iron production. Iron production remains were predominantly linked to group B and Middle Iron Working-Late Iron Working ceramic traditions (Walz 2010, p. 268). A furnace at the site of Jiko on the South Pare footslopes - dated to cal. AD $1095 \pm$ 43 (Beta-260835) - had a diameter of $86 \mathrm{~cm}$, with the remaining furnace wall measuring $63 \mathrm{~cm}$ high (Walz 2010 , p. 268), larger than those documented by Soper (1967) and those described in the historical accounts (Baumann 1891; Kotz 1922).

In North Pare, Henry Fosbrooke - a colonial officer and government sociologist with a personal interest in anthropology — provided descriptions of several archaeological sites associated with iron working (Fosbrooke 1954, 1957). In the following decades, more formal archaeological survey was undertaken by Knut Odner (1971), who recorded smelting sites in Usangi, Mwanga, Ngalanga, Campi ya Simba, Mpungonyi, Kifaru and Lembeni. Iron slag and tuyères were found throughout excavations at a site near Usangi Hospital, dating to the second half of the first millennium $\mathrm{AD}$, 
a

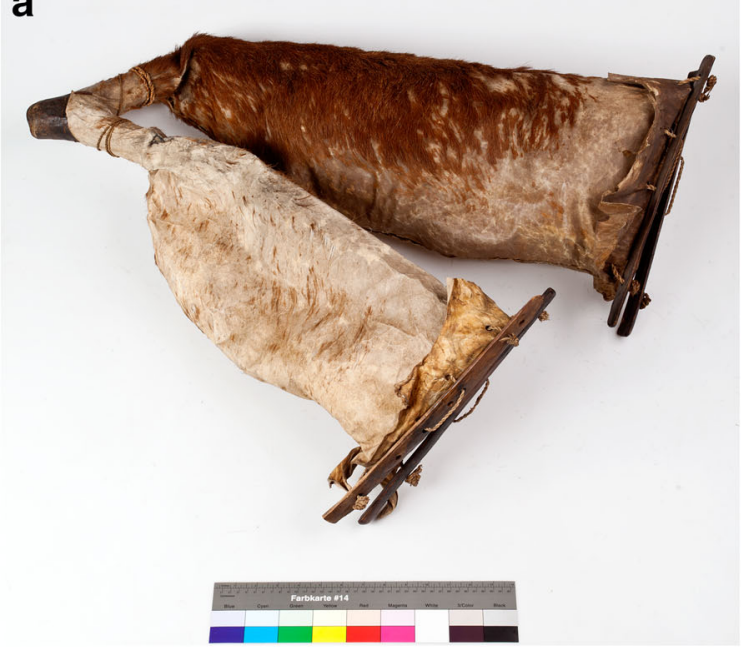

C

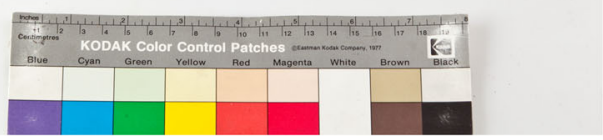

b
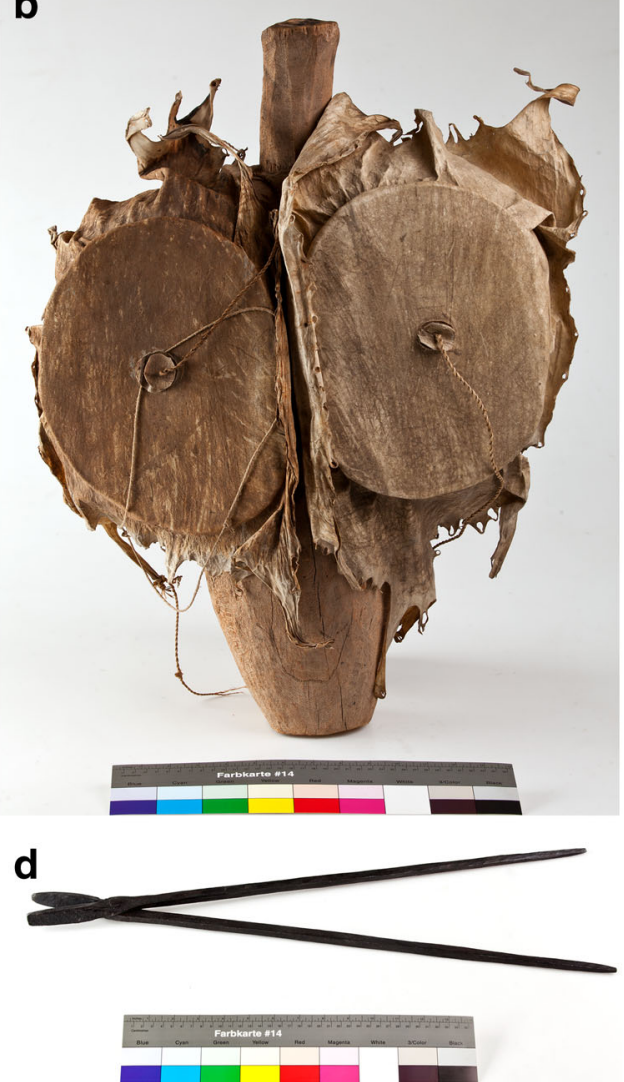

Fig. 3 Iron smithing items collected by Hans Fuchs in the early twentieth century in North Pare, held in the ethnographic collections of the Náprstek Museum, Prague. a Goat-skin bellows, b

which Odner suggested was indicative of iron smelting at the site. A similar date was proposed for smelting remains at the sites of Mwanga IIIA and Mwanga IIIB. Several other smelting sites-Mwanga I, Mwanga II and Vuchama Vunja-were thought to date to the

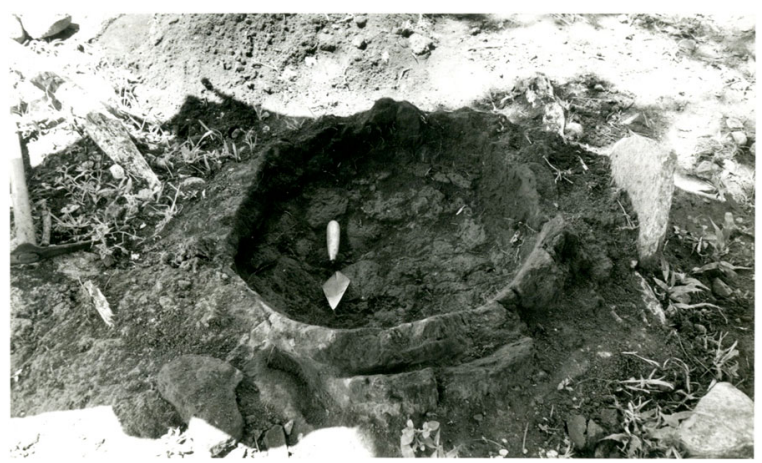

Fig. 4 Furnace at Makanya Kasapo (photo: Robert Soper) (ㄷ British Institute in Eastern Africa photographic archive, reproduced with permission) bowl bellows, $\mathbf{c}$ hammer and $\mathbf{d}$ tongs. (photos: Náprstek Museum, Prague, reproduced with permission)

nineteenth century, while Odner (1971, p. 119) stated that the site of Ngalanga was still being used for smithing at the time of his research. In contrast to Usambara, no evidence for Early Iron Age iron production has yet been identified in North Pare.

\section{New Archaeometallurgical Research in North Pare}

Since 2009, archaeological and archaeometallurgical research has been undertaken as part of two European Union-funded projects - HEEAL (Historical Ecologies of East African Landscapes, Principal Investigator Paul Lane) and EnvIron (Impacts of Metallurgy: Iron Production and the Environment in the Pare Mountains, Tanzania, Principal Investigator Louise Iles). This research has examined sites in North Pare in order to document in more detail the iron production industries of the area, explore the social and environmental 
impacts that these industries may have had and place these in a wider historical ecology framework (Lane 2010). Fieldwork undertaken between 2009 and 2014 confirmed anecdotal and historical suggestions and prior archaeological research that North Pare was a major hub of iron production, due to the frequency and concentration of archaeometallurgical remains encountered in this area. Metallurgical sites were found through targeted foot-survey in the drier and hotter lowland plains and foothills $(n=11)$, as well as the wetter and cooler upland areas $(n=14)$ (Fig. 5a-c). Presumably, more sites are yet to be located, although the extent of erosion in the highlands means that many are likely to have been eroded away, and others have probably been buried by the accumulation of colluvial deposits now known to be up to $4 \mathrm{~m}$ deep across the lower pediment and footslopes (Heckmann 2014; Heckmann et al. 2014). Several of the surviving sites show evidence for large-scale or prolonged industry in the form of considerable accumulations of slag blocks and slag fragments, substantial piles of discarded tuyères and preserved furnace remains. Analysis of these remains is presented in full elsewhere, including a discussion of the quantity of charcoal needed to fuel these technologies (Iles in preparation a). Smithing remains are also found at highland sites, including the remains of unusual stone bowls, anecdotally associated with the quenching of iron objects (Iles in preparation b).

Of the major sites recorded (Table 1), six were targeted for further excavation: Mwanga $\mathrm{A}$ and $\mathrm{C}$ because these had visible iron smelting furnaces, Mwanga $\mathrm{G}$ due to the very large quantity of smelting refuse, Ngalanga due to its significance in oral histories as the original settlement of the Washana clan of ironworkers and Campi ya Simba and Butu in order to investigate lowland smelting on the eastern side of the highlands. We discuss the characteristics and dating of these sites in the following sections.

\section{The Western Lowlands: Mwanga}

Seven discrete smelting sites, some of which have been dated to the late first and second millennia $\mathrm{AD}$, are located close to the modern town of Mwanga, situated on the plains to the western edge of the North Pare mountains (Fig. 1). The archaeological sites are located to the east of the town, with the majority found in the lower footslopes (Mwanga A to D), while others
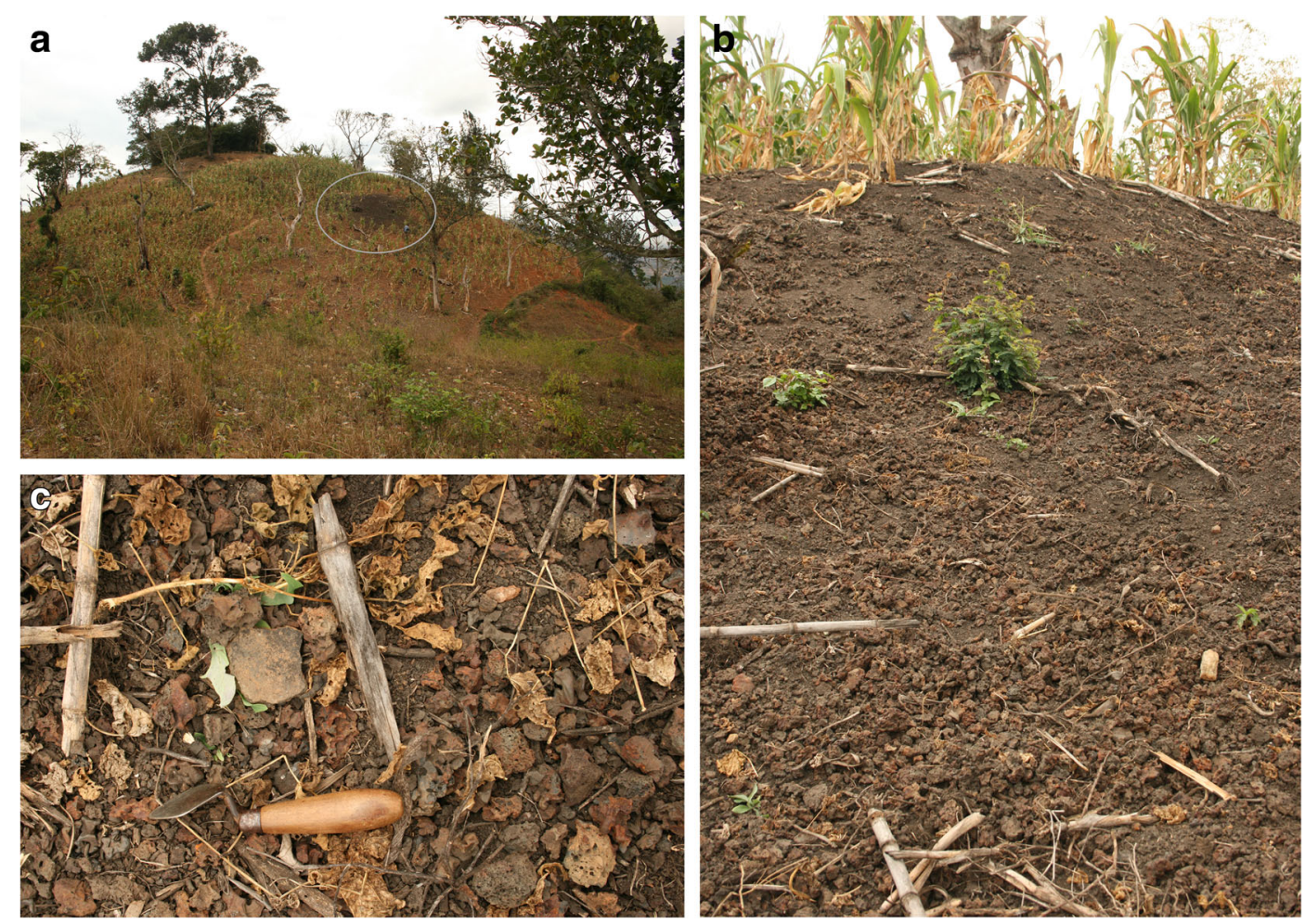

Fig. 5 a Upland iron working slag scatter near Mbore. b Inset of upland slag scatter. c Close-up of surface scatter (photos: P. Lane) 


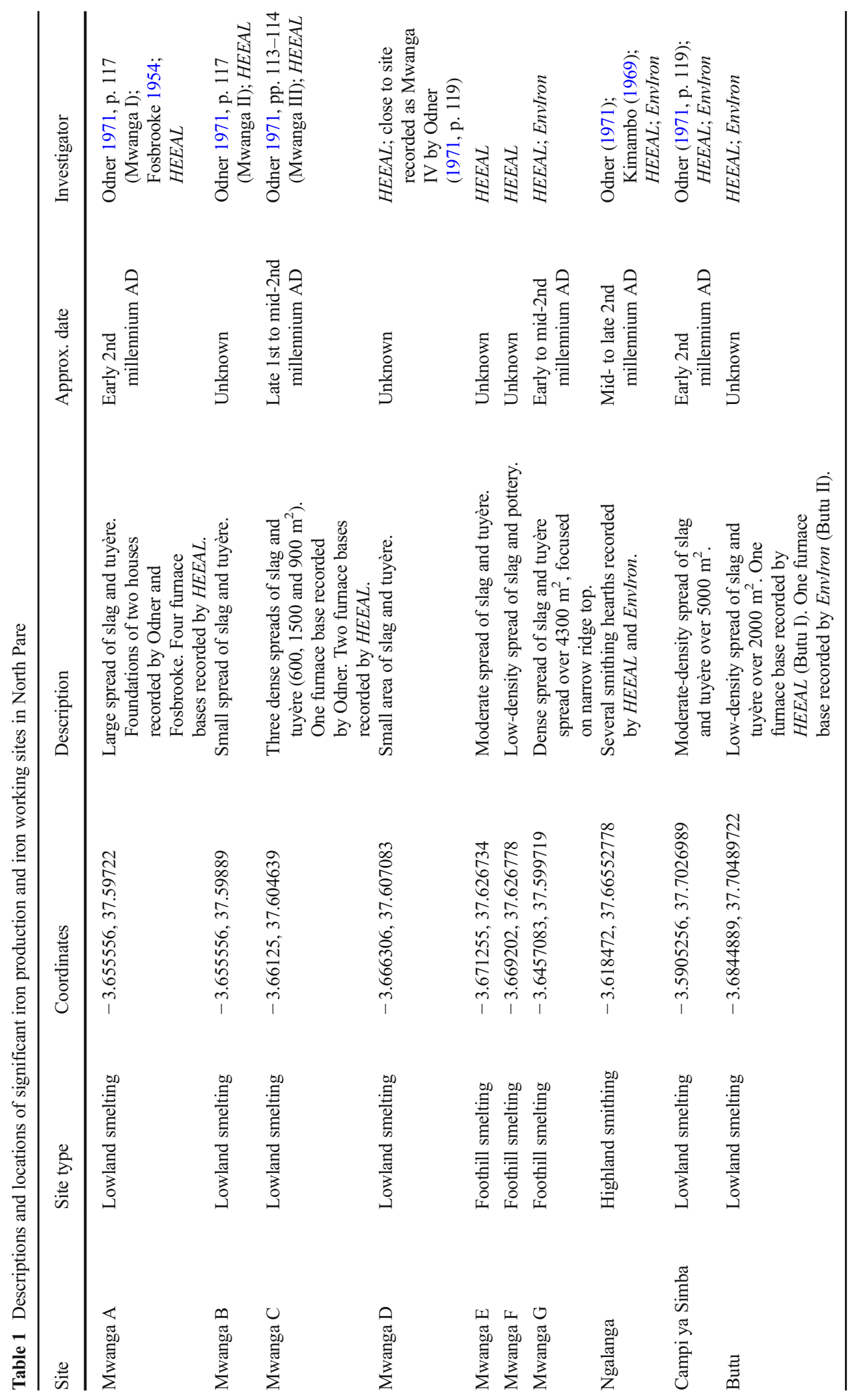


(Mwanga E, F and G) are situated in the foothills on ridges approximately $300 \mathrm{~m}$ above the lowland footslope sites and Mwanga town itself (Fig. 1). The Mwanga sites are generally typified by scatters of slag and tuyère, variable in the extent of their spread and the density of finds (cf. Table 1).

\section{Mwanga A}

The site of Mwanga A is located to the immediate north of the Mwanga-Usangi road, and was initially recorded by Odner (1971, p. 117) as Mwanga I. The designation of Mwanga A was assigned to draw a clear distinction between Odner's survey and the more recent work, not least because Odner's description of the site does not correspond with the remains visible in 2010-2014, when surface finds of pottery were extremely rare and the house foundations reported by Odner could not be relocated. From Odner's description of the site location and coordinates, it is nevertheless now clear that Mwanga A is the same site as Odner's Mwanga I, and it would seem most probable that the house foundations have subsequently been eroded away, a conclusion supported by the presence of multiple erosion rills and plant pedestals of up to $35 \mathrm{~cm}$ of sediment across the site.

In 2010, four furnaces were excavated at Mwanga A; although only the bases of the furnaces survived in three of these examples, one was considerably better preserved. This example measured $70 \mathrm{~cm}$ in diameter and $44 \mathrm{~cm}$ deep, and consisted of a baked sandy-clay furnace lining that followed the form of a circular pit with steep, near vertical sides and a shallow concave base (Fig. 6). This furnace was filled with a dark reddish-

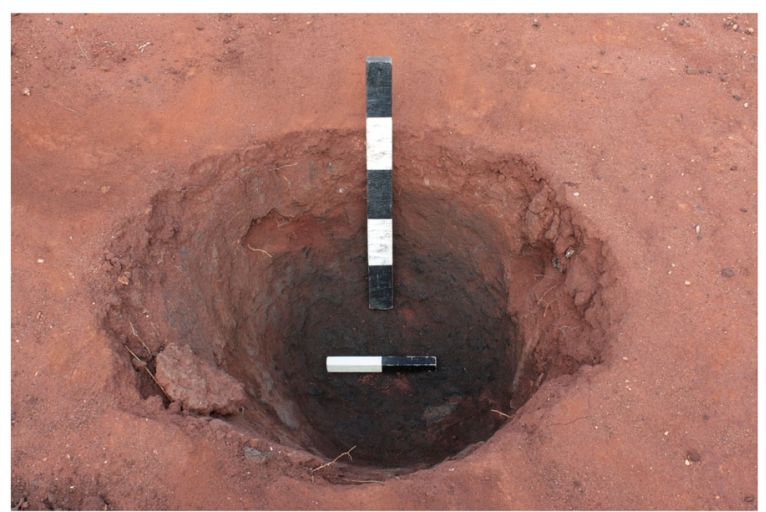

Fig. 6 Furnace [46], Mwanga A, dated as LTL5138A (scales in $10 \mathrm{~cm}$ increments). (photo: D. Stump) brown sandy clay loam with occasional fragments of charcoal and slag, but with very common (c. 25\%) fragments of tuyères, all of which had evidently been used and some of which seemed near complete. Given the sheer number of tuyères that litter the surface of this site, it is possible that the furnace was left open after use and that the material discarded on the surface nearby slowly accumulated within the open furnace pit. However, it is equally possible that the furnace pit was deliberately backfilled with iron working refuse.

Although it cannot be certain that a radiocarbon determination based on charcoal from the furnace fill accurately dates the firing of this structure, it nevertheless clearly relates to smelting activity at Mwanga A more generally, and produced a calibrated date range of between the mid-eleventh and mid-thirteenth centuries AD (see Table 2), which is in agreement with the diagnostic pottery found at the site by Odner (1971).

\section{Mwanga $C$}

The smelting site of Mwanga $\mathrm{C}$ is located approximately $1 \mathrm{~km}$ to the east of Mwanga A, and comprises three sizeable spreads of slag and tuyère as well as several well-preserved furnace bases. Odner's excavations at the site recorded a clay-lined furnace approximately $50 \mathrm{~cm}$ in diameter (see Odner 1971, plate IVb), although this was not excavated. In 2010, two furnace bases with in situ baked clay linings were excavated, both measuring c. $90 \mathrm{~cm}$ in diameter and $55 \mathrm{~cm}$ deep (Fig. 7a, b), located just $80 \mathrm{~cm}$ apart. This proximity and their similarity in terms of dimensions and form-both having steep sides of c. $70-80^{\circ}$ with a shallow concave basesuggests that they are roughly contemporary. The fills of both furnaces are also similar, the sole fill of one furnace and the upper fill of the other both being a very compact clay loam, reddish yellow in colour, with occasional slag, tuyère and charcoal fragments. The second of the two furnaces also contained a dark grey primary fill, the colour of which evidently derived from high concentrations of charcoal flecks, and which also contained occasional larger charcoal fragments and small pieces of slag. Intact slag blocks at the site measured 10-20 cm in depth, and 20-30 cm in diameter (original diameters were estimated where slag blocks had been fractured or broken after deposition).

Charcoal from this deposit produced a calibrated radiocarbon date range of between the fourteenth and mid-fifteenth centuries $\mathrm{AD}$, somewhat later than the 
Table 2 Radiocarbon dates associated with iron production and iron working sites in North Pare

\begin{tabular}{|c|c|c|c|c|c|c|}
\hline Site & Feature/deposit & Lab code & C14 age & Calibrated date (SHCal 13) & Calibrated date (IntCal 13) & Reference \\
\hline Mwanga A & Furnace fill & LTL5138A & $862 \pm 40 \mathrm{BP}$ & 1157-1278 AD & $1044-1260 \mathrm{AD}$ & $H E E A L$ \\
\hline \multirow[t]{2}{*}{ Mwanga C } & No context info. & $\mathrm{N}-649$ & $1020 \pm 110 \mathrm{BP}$ & 791-1275 AD & 769-1244 AD & Odner 1971 \\
\hline & Furnace fill & LTL5140A & $560 \pm 50 \mathrm{BP}$ & 1316-1459 AD & $1298-1436 \mathrm{AD}$ & $H E E A L$ \\
\hline \multirow[t]{2}{*}{ Mwanga G } & Tuyère pile & LTL5139A & $366 \pm 45 \mathrm{BP}$ & 1461-1643 AD & $1447-1636 \mathrm{AD}$ & HEEAL \\
\hline & Slag-rich deposit & AA103978 & $873 \pm 36 \mathrm{BP}$ & 1155-1274 AD & $1042-1248 \mathrm{AD}$ & EnvIron \\
\hline Campi ya & Slag-rich deposit & AA103979 & $900 \pm 36 \mathrm{BP}$ & 1048-1270 AD & $1036-1213 \mathrm{AD}$ & EnvIron \\
\hline \multirow[t]{3}{*}{ Simba } & Slag-rich deposit & AA103980 & $927 \pm 36 \mathrm{BP}$ & $1045-1223$ AD & $1024-1185 \mathrm{AD}$ & EnvIron \\
\hline & Slag-rich deposit & AA103981 & $945 \pm 36 \mathrm{BP}$ & $1040-1213$ AD & $1020-1165 \mathrm{AD}$ & EnvIron \\
\hline & Slag-rich deposit & AA103982 & $900 \pm 36 \mathrm{BP}$ & 1048-1270 AD & $1036-1213$ AD & EnvIron \\
\hline \multirow[t]{5}{*}{ Ngalanga } & Ditch fill & LTL5136A & $194 \pm 45 \mathrm{BP}$ & post-1655 AD & post-1642 AD & $H E E A L$ \\
\hline & Ditch fill & AA103983 & $236 \pm 41 \mathrm{BP}$ & post-1631 AD & post-1520 AD & EnvIron \\
\hline & Smithing hearth & AA103976 & $278 \pm 42 \mathrm{BP}$ & 1504-1804 AD & post-1479 AD & EnvIron \\
\hline & Pit fill & AA103975 & $261 \pm 41 \mathrm{BP}$ & 1508-1876 AD & post-1490 AD & EnvIron \\
\hline & Feature fill & AA103974 & $245 \pm 41 \mathrm{BP}$ & post-1517 AD & post-1515 AD & EnvIron \\
\hline
\end{tabular}

All dates have been calibrated using OxCal 4.2, to 95.4\% probability (Bronk Ramsey 2009; Hogg et al. 2013; Reimer et al. 2013)

dates resulting from Odner's excavation, which produced a radiocarbon date range of between the late eighth to the mid- to late-thirteenth centuries (Table 2), and Group B pottery (Odner 1971, p. 113) - a ceramic form which has generally been dated to between $\mathrm{AD}$ 900 and 1200 (e.g., Walz 2010, pp. 315-316). Questions as to the exact context of recovery of this pottery aside, it would nevertheless seem fair to conclude that the site broadly dates to between the thirteenth and fifteenth centuries, and indeed may have been used continually, recurrently or periodically for iron smelting for an extended period, conceivably a century or more.

\section{Mwanga $G$}

The final Mwanga smelting site examined in detailMwanga $\mathrm{G}$ - is located in foothills to the east of Mwanga town. Although occasional redeposited surface finds of slag are apparent at the base of this hill, especially after rain, it is likely that they originate upslope, at a smelting site situated on a narrow ridge-top at a mid-slope position, approximately $960 \mathrm{~m}$ asl. The site comprises an incredibly dense concentration of slag and tuyère covering much of the ridge-top as well as eroding down the steep hillside. It is probable that this site correlates with that described by Fosbrooke (1954, p. 102):
This site is a projecting foothill, and the little plateau on the ridge was used time and again for a smelting site. The evidence indicates that after each smelting the site was swept clear; for on the hillside below there is a veritable scree slope of broken clay bellow mouths (tuyères) and lumps of slag. A count of bellow mouths over a limited area and the pacing of the total area indicate that there are at least 800 bellow mouths exposed on the surface alone; how many more are hidden can only be ascertained by excavation.

In 2010, an initial attempt was made to locate the furnaces associated with this smelting debris, first by investigating a neat pile of approximately 100 used and discarded tuyères (Fig. 8). The lowermost of these tuyères were partially buried by a layer of sandy clay loam containing frequent tuyère fragments and charcoal, a sample of which was dated to between the midfifteenth to mid-seventeenth centuries (Table 2). The sheer density of smelting refuse suggests that production activity was intense at the site, but despite the limited number of possible locations for a furnace on this narrow ridge, the excavation of a total surface area of $64 \mathrm{~m}^{2}$ between 2010 and 2014-including magnetometerguided test-pitting - failed to locate the remains of a single furnace. Nevertheless, the test-pits provided a 

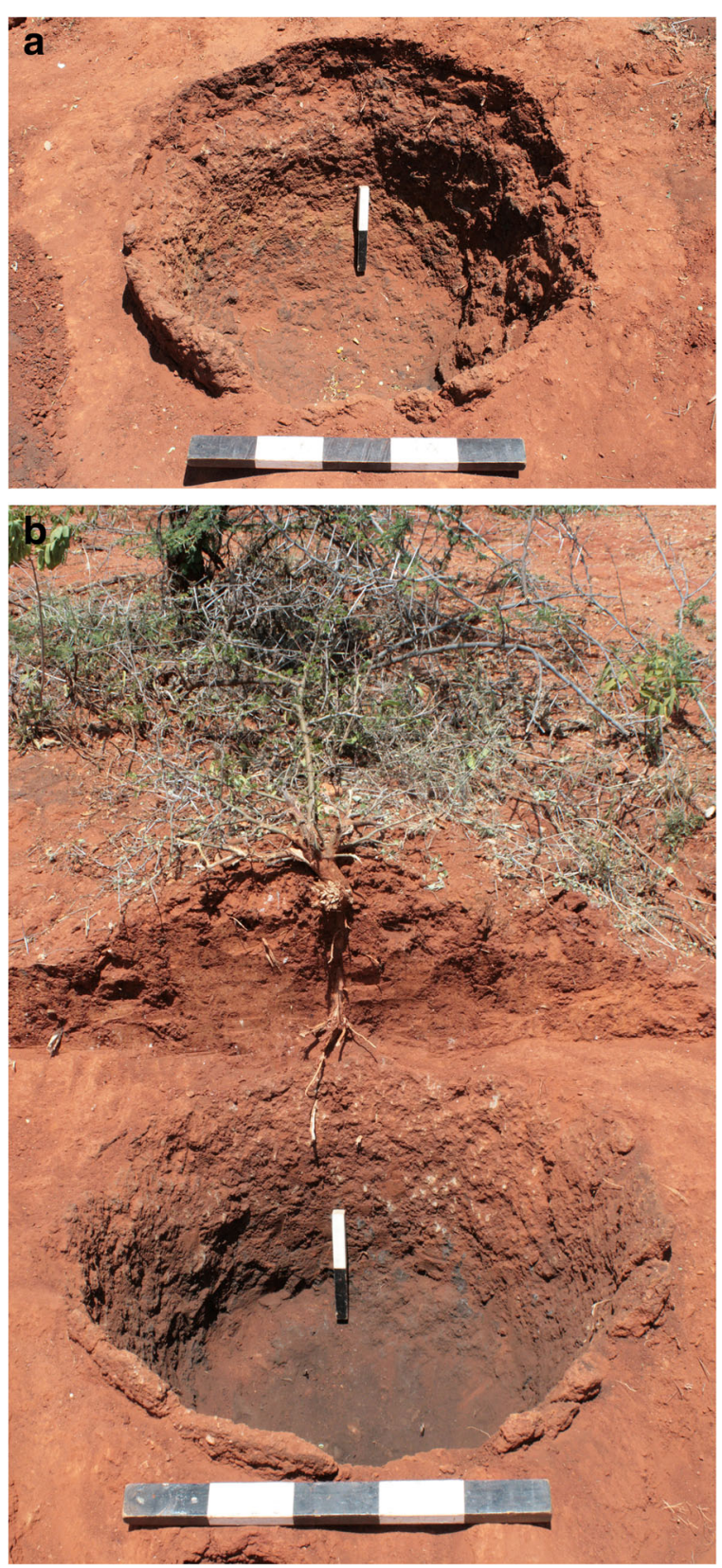

Fig. 7 a, b Furnaces [71] and [75], Mwanga C (scales in $10 \mathrm{~cm}$ increments). (photos: D. Stump)

valuable overview of the distribution of archaeological deposits at Mwanga $\mathrm{G}$, and intact slag blocks at the site measured $10-15 \mathrm{~cm}$ in depth, and $25-40 \mathrm{~cm}$ in diameter.

Two sherds of decorated pottery were, however, found in a slag- and tuyère-rich deposit at the site (Fig. 9a, b). The pottery appears to be from a narrowmouthed bowl (Fig. 9a) and a necked pot (Fig. 9b), with some resemblance in terms of vessel form to Group A

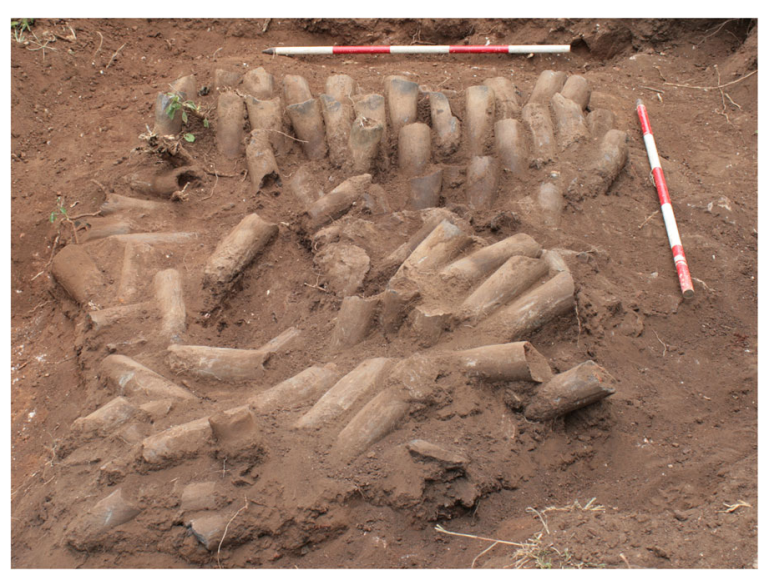

Fig. 8 Pile of tuyères at Mwanga $G$

Maore ware (cf. Soper 1967, p. 26; Walz 2010, pp. 243, 259). There are particular similarities between that illustrated in Fig. 9a and reconstructed vessels from the Chyulu Hills, Kenya (Soper 1976) and sherds from the Usangi Hospital site (Odner 1971). In terms of decorative motifs, the horizontal incised lines present on the vessel in Fig. $9 \mathrm{~b}$ bear resemblance to the horizontal comb marks on Group B sherds from Kwa Mgogo (Walz 2010, p. 192, Fig. 6). Group B pottery includes round-bottomed globular pots (or jars) with necks (independent restricted vessels) or restricted or unrestricted bowls, the former with slight carinations. Most sherds are reddish-brown in colour with dark (black to grey) cores (Odner 1971, p. 113). Odner (1971, pp. 113-114) found Group B pottery at several other Mwanga smelting sites.

The deposits associated with these ceramics at Mwanga $G$ were dated to between the mid-eleventh or mid-twelfth century AD and the mid-thirteenth century $\mathrm{AD}$ (Table 2), somewhat earlier than the date obtained at the tuyère dump on the lower plateau. Although not conclusive, together these dates might suggest that either continuous or episodic smelting activity was undertaken at Mwanga $\mathrm{G}$ over the course of several hundred years, broadly contemporaneous with iron production activity at other Mwanga sites.

The Eastern Lowlands: Campi ya Simba and Butu

Two further smelting sites were investigated on the eastern side of the Pare mountains: Campi ya Simba and Butu. Campi ya Simba is a lowland smelting site situated at approximately $760 \mathrm{~m}$ asl on the north-eastern escarpment of the Pare mountains, positioned where the 
a

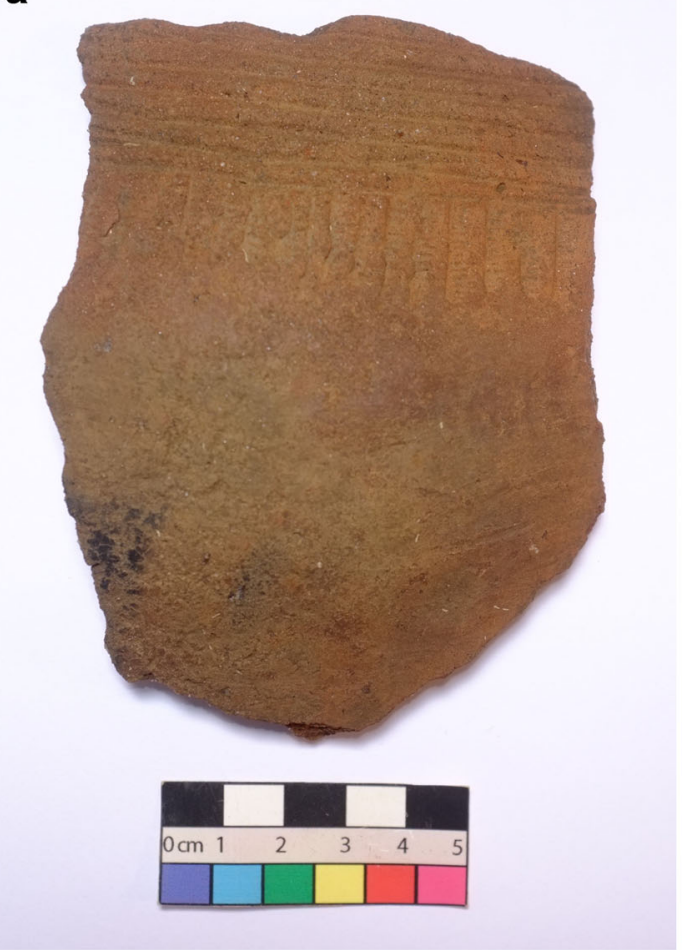

Fig. 9 a, b Decorated pottery from Mwanga G. (photos: L. Iles)

lower foothills of the North Pare mountains meet the plain (Fig. 1, Table 1). The site - briefly mentioned by Odner (1971, p. 119) — lies at the base of an historic irira cattle path and extends approximately 100 m northsouth along the flank of the Nbuchi hills. Four clusters of smelting activity-indicated by surface concentrations of slag and tuyère, often interspersed with frequent fragments of unfired ceramic building material—were apparent from an initial walking survey.

Magnetometer survey was carried out in 2014, covering an area of approximately $130 \mathrm{~m}^{2}$. Four excavation units were opened, including three $1 \mathrm{~m} \times 1 \mathrm{~m}$ test units to explore anomalies detected through the magnetometry. However, all these units revealed an archaeologically sterile subsoil characterised by a yellowish-red, compacted clay loam. A final $2 \mathrm{~m} \times 2 \mathrm{~m}$ test unit was positioned in an area with a strong magnetometer response that was also in an area visibly rich in surface slag and tuyère remains. Excavation exposed a thin layer of hill-wash containing a significant volume of iron production remains $(65.5 \mathrm{~kg}$ of slag and $1.5 \mathrm{~kg}$ of tuyère), overlying a lower ashy grey deposit that covered approximately two thirds of the trench and extended approximately $25 \mathrm{~cm}$ in depth. This ashy layer was

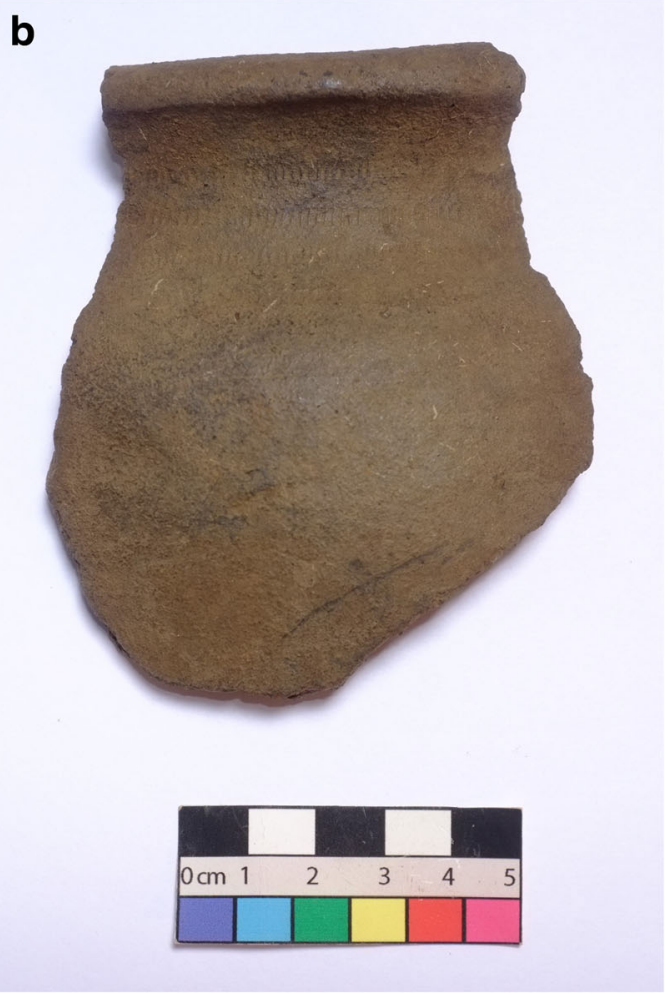

even richer in iron production remains, containing $323 \mathrm{~kg}$ of slag and $7 \mathrm{~kg}$ of tuyère as well as several pieces of furnace lining. Four charcoal samples from the ashy deposit place its likely formation in the eleventh to thirteenth centuries AD (Table 2); ages of the samples excavated from this context - when combined using OxCal 4.2-calibrate to 1070-1219 cal. AD (ShCal 13) or 1038-1162 cal. AD (IntCal 13), with $95.4 \%$ probability. Unfortunately, no furnace remains were revealed. Intact slag blocks at the site measured 5-14 cm in depth, and $25-30 \mathrm{~cm}$ in diameter.

Butu is another lowland smelting site in the escarpment to the east of the Pare mountains (Fig. 1, Table 1). A 2009 survey of the area noted several surface scatters of slag and a furnace base (Butu I). In 2011, the furnace base previously recorded could not be relocated, and it is possible that erosion had since destroyed the remains. However, a second small smelting area was located, situated slightly higher in the foothills (Butu II), where the partial remains of a furnace base were found eroding from a small gully. The flat furnace base was approximately $2.5 \mathrm{~cm}$ thick, with a maximum surviving diameter of $30 \mathrm{~cm}$, appearing to widen to a maximum $50 \mathrm{~cm}$ diameter above. The walls of the upper furnace lining 
were very heavily eroded, only coherently surviving to a height of c. $3 \mathrm{~cm}$ above the furnace base, yet traces of burning suggest that the furnace originally extended to at least 20 to $25 \mathrm{~cm}$ in height. Due to the sparse and fragmentary remains at Butu, no excavation was undertaken, but several samples of surface slag and tuyère were collected for further analysis. Intact slag blocks at the site measured $5-10 \mathrm{~cm}$ in depth, and $30-35 \mathrm{~cm}$ in diameter.

\section{The Highlands: Ngalanga}

Walking survey was conducted in upland areas, especially in the vicinity of known irira cattle paths, as interviews with elders suggest that this may have been a preferred location for smithing activity (M. Sheridan pers. comm. 2009). Irira and iron were closely linked; metal flowed up the cattle paths from the smelting sites, while wood and charcoal flowed down (Mzee J. Mturi, Usangi, interview 9 June 2004, M. Sheridan). In all, 14 areas of highland iron processing activity were located (Figs. 1 and 5). However, only one site, Ngalanga-a smithing site located in the Ugweno highlands (Fig. 1, Table 1) on a north-east facing slope at a height of $\mathrm{c}$. $1400 \mathrm{~m}$ asl - was investigated further.

Ngalanga consists of a low-intensity scatter of slag and tuyère fragments in and around cultivated plots. The remains are consistent with those that would be expected at a smithing site, including small slag smithing cakes and hammerscale. Oral histories record Ngalanga as the original settlement of the Washana clan of iron workers (from the Bantu root "sana", "shana" or "chana" meaning iron working or craftsmanship [Sutton 1972, p. 38]), and it remains the site of the Washana sacred forest, situated directly upslope of the archaeological smithing remains. Kimambo (1969) and Odner (1971) noted the significance of Ngalanga as an historic centre of iron working - and a Washana smith continues to work nearby-but no archaeological work had been undertaken prior to 2010. Excavations were undertaken in 2010, 2011 and 2014, and confirmed that this was an area that was intensively used for smithing activity in the second half of the second millennium AD.

In 2010, investigation of a road cut leading from the main road up to the sacred forest revealed two small smithing hearths associated with a charcoal-rich layer $\mathrm{c}$. $30 \mathrm{~cm}$ deep, with one hearth showing evidence for several relining events (Fig. 10). A section was also excavated into a ditch revealed in the road cut, the fill

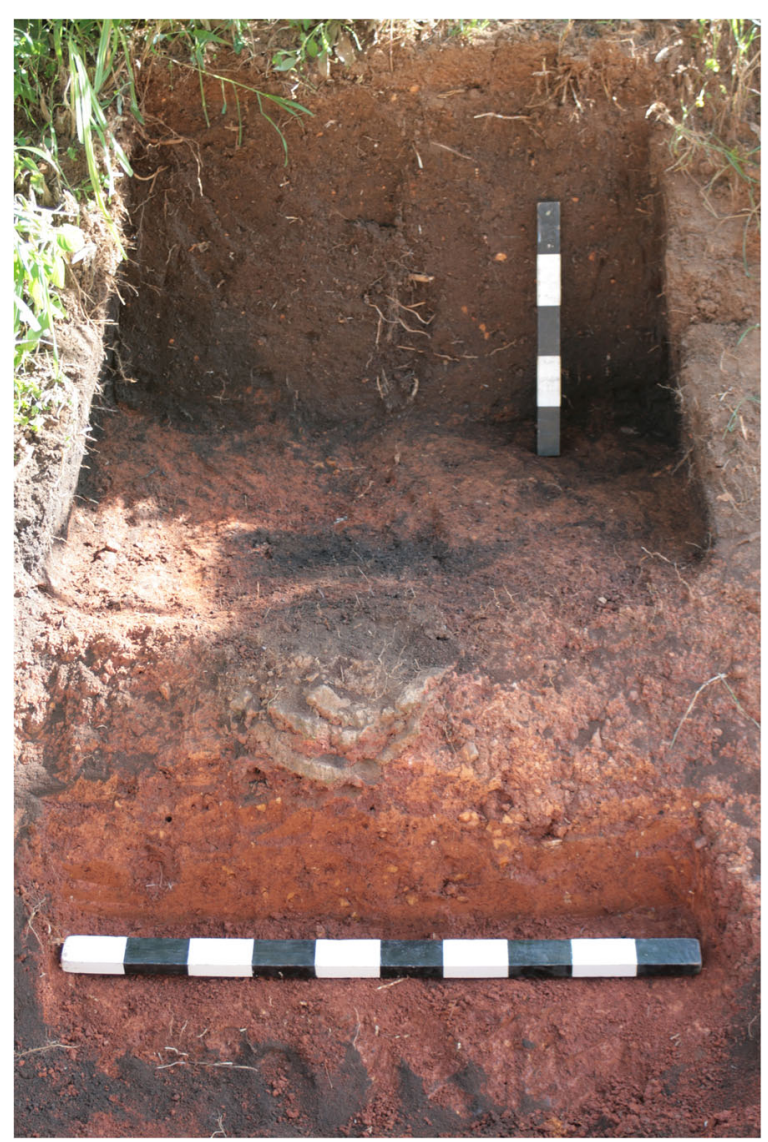

Fig. 10 Remains of a re-lined smithing hearth at Ngalanga (scale bars in $10 \mathrm{~cm}$ gradations). (photo: D. Stump 2010)

of which-radiocarbon dated to after the midseventeenth century AD (Table 2) — was found to contain abundant tuyères and slag fragments, rare pottery sherds and a near-complete stone bowl. An additional segment of this ditch - further upslope — was excavated in 2011, generating a similar date (Table 2).

In 2011, excavation of a $2 \mathrm{~m} \times 2 \mathrm{~m}$ trench exposed a mixed ashy deposit approximately $25 \mathrm{~cm}$ thick, with a high concentration of charcoal, hammerscale and tuyère fragments in the eastern side of the trench, and redeposited hillwash on the west. Further excavation revealed smithing-related features within this trench, including small, circular, clay-lined pits and an unlined smithing hearth (context [7] in Fig. 11). Radiocarbon dates obtained on charcoal taken from the fills of these features calibrated to a broad post-sixteenth century $\mathrm{AD}$ range (Table 2).

Excavation continued in this part of the site in 2014 in order to expose more of the smithing area. Removal of a layer of upcast from road-cut clearance exposed 


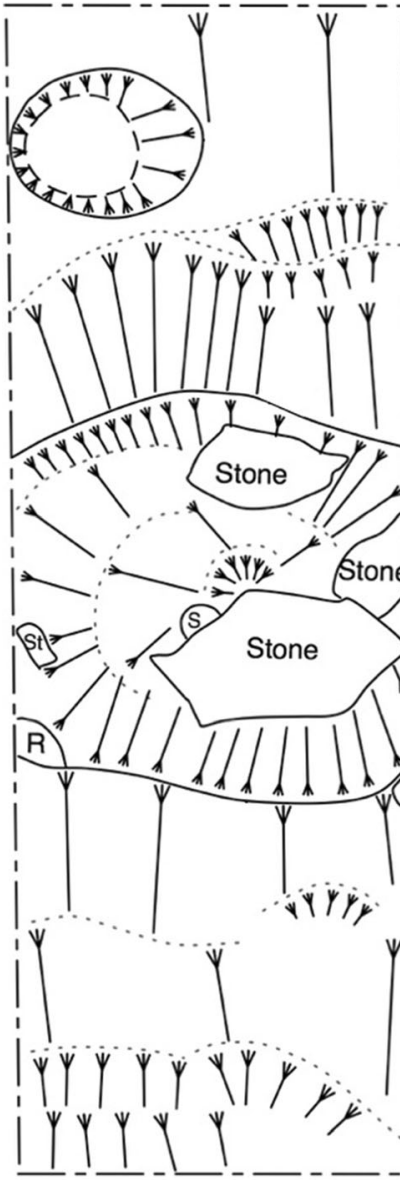

Trench extension $1 \mathrm{~A}$

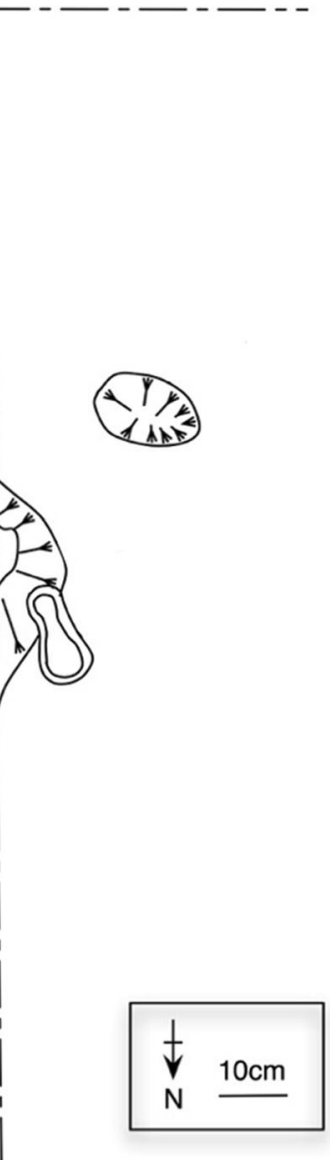

Trench 1
Fig. 11 Plan of excavated smithing area at Ngalanga, 2011. $R$ root, $S t$ stone, $S$ slag]

topsoil across the entire trench, beneath which was a mixed ashy layer approximately $30 \mathrm{~cm}$ thick containing small pieces of slag $(3 \mathrm{~kg})$ and tuyère $(1.5 \mathrm{~kg})$, as well as several fragments of corroded iron and undecorated pottery. At the southern end of the trench, this ashy layer overlay a compacted, archaeologically sterile subsoil characterised by a yellowish-red clay loam. In the northern part of the trench, the ashy layer came down onto the fill of a pit or depression that led down towards the smithing area excavated in 2011. Two smaller features were also cut into the underlying sterile compacted clay loam. One was a small oval depression (c. $50 \mathrm{~cm} \times$ $25 \mathrm{~cm}$ in plan, and $10 \mathrm{~cm}$ deep) with gently sloping sides - baked hard by fire - a flat, blackened base, and a very charcoal-rich fill (containing an iron nail, bone, tuyère and slag). It is likely that this feature was a smithing hearth, dated to the second half of the second millennium $\mathrm{AD}$ (Table 2). The other feature was c. $12 \mathrm{~cm}$ in diameter and $7 \mathrm{~cm}$ deep, potentially marking the position of a driven post. In the north-facing section of the trench, a further posthole was also visible, suggestive of a smithing hut similar to those seen in the region today (Fig. 12a) and in the recent past (Fig. 12b).

\section{Past Iron Production Technologies of North Pare}

The archaeometallurgical component of this research sought to reconstruct the smelting technologies of North Pare. As indicated above, the investigated archaeological sites are of variable date and hence it is not yet possible to reconstruct the complete chaîne opératoire
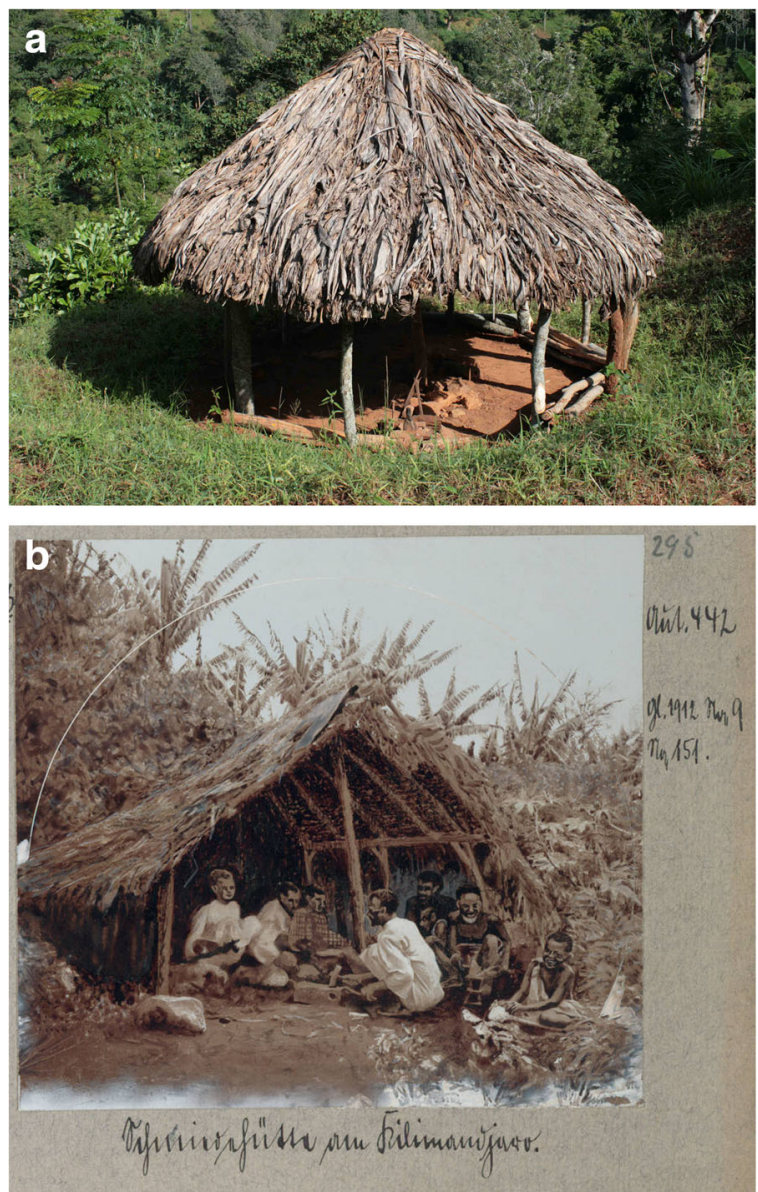

Fig. 12 a Modern smithing hut close to Raa, Pare, 2010 (photo: D. Stump). b Forge hut at Kilimanjaro, Tanzania, c. 1900-1912 ("Schmiedehütte am Kilimanjaro"). (photo: (C) EvangelischLutherisches Missionswerk Leipzig e.V., IMP-LPZ-DVMB-IXf295 , reproduced with permission) 
for any period. The results, nonetheless, greatly supplement the available documentary information and permit valuable technical comparison with similar but distinct iron making practices elsewhere in the region.

A detailed macroscopic examination was made of 31 slag blocks from eastern Pare (Butu I and II, $n=8$; Campi ya Simba, $n=23$ ) and 58 slag blocks from western Pare (Mwanga C, $n=20$; Mwanga G, $n=38$ ), selected from distinct clusters of smelting activity at these sites, in addition to three fragments of slag excavated from the furnace at Mwanga $C$. Initial visual analysis found the Mwanga slag blocks to be very similar. They were generally fractured and broken; only four slag blocks (all from Mwanga G) were complete. They were relatively shallow (5-20 cm deep), circular to oval in plan and ranged between 20 and $40 \mathrm{~cm}$ in diameter. The blocks tended to have concave upper surfaces, with a band of plant impressions (typically small grasses) around the middle. The dimensions and shape of the slag blocks presented no contradictions in associating them with the furnace remains excavated at Mwanga A and $\mathrm{C}$, i.e., moderately deep cylindrical pit bases.

Similarly, only three slag blocks from eastern Pare were complete, all from Campi ya Simba; the remainder showed at least one fractured edge. The slag blocks themselves were similar to those on the western flank of the hills: they had flattened bases, with indentations around the middle where plant impressions were concentrated. Unlike at Mwanga, some papyrus impressions were visible on these slag blocks, presumably due to the proximity of the eastern sites to Lake Jipe and its associated papyrus swamps. The slag blocks were oval in original shape and tended to be relatively shallow, measuring only 5-14 cm deep (slightly smaller than the Mwanga slag blocks) and with estimated original diameters (before breakage) of between 15 and $30 \mathrm{~cm}$. This suggests that they might have formed in furnaces that were smaller than at Mwanga, which is supported by the smaller diameter of the furnace found at Butu II.

Chemical and mineralogical compositions of a representative sub-sample of the Mwanga and eastern flank slag blocks were obtained through wavelengthdispersive X-ray fluorescence (WD-XRF) analysis undertaken at the Department of Geological Sciences, University of Cape Town (Mwanga, $n=43$; eastern, $n=26$ ), optical microscopy (Mwanga, $n=21$; eastern, $n=10$ ) and electron probe micro-analysis (EPMA) undertaken at the Institute of Archaeology, UCL and the
Department of Space Sciences, University of Arizona (Mwanga, $n=7$; eastern, $n=5$ ), the results of which will briefly be discussed here (for a summary of the WD-XRF results, see Table 3. For full method and results, see Iles in preparation a). Samples of tuyère and black sand from each site were also analysed.

Bulk chemical analysis of all the smelting slag found that it contained on average c. $21 \mathrm{wt} \% \quad \mathrm{TiO}_{2}$ $(\mathrm{SD}=3)$, which was reflected in the presence of titania-rich ulvöspinels (ulvite, $\mathrm{TiFe}_{2} \mathrm{O}_{4}$ ) in the slag matrix (Fig. 13). Of note, the modern samples of black sand-sampled from sources near Mwanga C, Mwanga G, Butu and Campi ya Simba-also displayed particularly high titania contents (Table 3), with up to $36 \mathrm{wt} \% \mathrm{TiO}_{2}$ and $55 \mathrm{wt} \%$ $\mathrm{FeO}$. This confirms that local ilmenite-magnetite $\left(\mathrm{FeTiO}_{3}-\mathrm{Fe}_{3} \mathrm{O}_{4}\right)$ black sands were used in Pare's iron production potentially as early as the eleventh century $\mathrm{AD}$ and continuing into the nineteenth and twentieth centuries as documented in the ethnohistorical literature. Suitable black sands were available in the immediate vicinity of all the smelting sites discussed, so ore would have been readily available to smelters working there-at least seasonally-depending on the sorting action of running water.

Due to the relative rarity of geological occurrences of this ore type, there are only infrequent examples of the use of similar titania-rich magnetite sands from archaeological and ethnographic sources in Africa. Second millennium AD iron producers in Laikipia, Kenya used an ilmenite-magnetite sand with a lower ratio of titania to iron oxide (c. $7 \mathrm{wt} \% \mathrm{TiO}_{2}$ to c. $49 \mathrm{wt} \% \mathrm{FeO}$; Iles and Martinón-Torres 2009). Ethnographic examples of the use of titania-rich ore sands are known from the Mount Kenya region (Routledge and Routledge 1910; Cline 1937; Brown 1995) and Kondoa (Mapunda 2003, 2013). Further afield, a similar ore has been documented in Yoruba smelting in south-west Nigeria (Ige and Rehren 2003; Ige 2013), and ilmenite-magnetite ores with a titania content comparable to that seen in Pare were used to smelt iron in the Lowveld of north-eastern South Africa, resulting in slag samples with up to $25 \mathrm{wt} \% \mathrm{TiO}_{2}$ (Killick and Miller 2014).

The macroscopic remains described above-notably the furnace remains and the lack of flow structure apparent on the slag blocks - indicate that the primary iron production technology used in North Pare was a non-slag tapping process; in a slag- 
tapping furnace, the molten slag would be periodically "tapped" from a furnace, i.e., allowed to flow into a pit outside of the main furnace structure; in a non-slag-tapping furnace (as documented here), the molten slag would drip down into a pit beneath the reduction zone (where the iron bloom develops) within the furnace itself. Both the slag analyses and the documentary accounts indicate that iron sand was smelted in pit furnaces dug into the ground. The configuration and design of any above-ground superstructure is currently unknown. However, the abundant, near-complete used tuyères from the site of Mwanga $G$ offer further insight into furnace design. These tuyères typically have drips and vitrification at the nozzle ends. The position of the drips indicates an angle of insertion into the furnace of around $30^{\circ}$ (Fig. 14), and as the vitrification extends only on the undersides of the tuyères to an extent of around $15 \mathrm{~cm}$, this might indicate the partial insertion of the tuyères into an open, not closed furnace, suggestive of a minimal superstructure and a potentially shallower furnace base than the excavated furnaces at Mwanga $\mathrm{A}$ and $\mathrm{C}$ (cf. furnaces described at Kasapo, South Pare, in Soper 1967, p. 29 and those described by Baumann 1891, p. 233). The number of tuyères used per furnace is unknown. While the ethnohistoric accounts generally refer to the use of single tuyères, the abundance of tuyères present at these smelting sites seems incongruous with this. Only the excavation of furnace remains with tuyère-ports surviving will be able to clarify this issue.

The tubular tuyères at Mwanga $G$ and at all other sites appear to be crudely made, with variable thickness walls (the thickness of the tuyère walls ranges between 1.5 and $3 \mathrm{~cm}$ on one single example), although most tend to have a thickness of around $1.5-2 \mathrm{~cm}$. The internal diameters are more regular, averaging $3-3.5 \mathrm{~cm}-\mathrm{a}$ size consistent with the use of bellows to introduce air into the furnace (Pleiner 2000, p. 198). All are composed of a yellowish-red clay, with frequent small quartz inclusions, and porosity relating to the use of organic temper. WD-XRF analysis of the tuyère fabrics indicated that they were highly refractory (meaning that they can withstand high temperatures), with an average of $21 \mathrm{wt} \%$ (standard deviation $(\mathrm{SD})=2$ ) alumina and low iron and lime contents. This means that they would have been well suited to 
Fig. 13 Photomicrograph showing ulvöspinels (pink, marked "U") and fine olivine lathes (light grey, marked "O") in a glassy matrix (dark grey). Iron metal appears white, and voids in the sample as black. (photo: L. Iles)

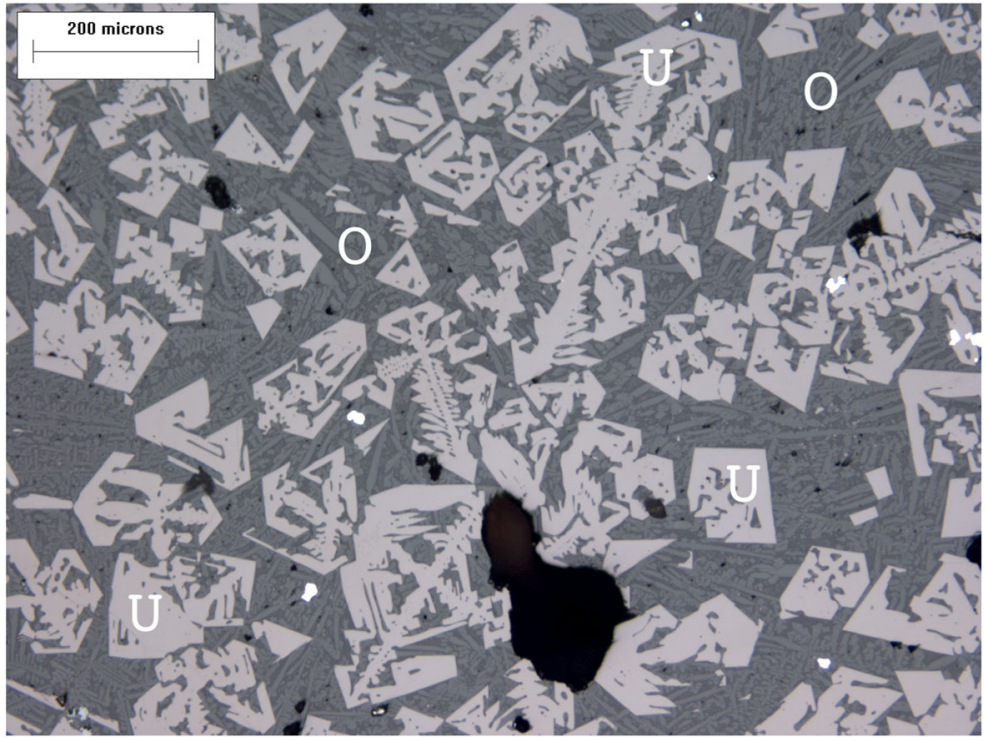

the high operating temperatures of an iron smelting furnace, reducing the likelihood of the clay melting significantly and blocking the air-flow into the furnace during a smelt. Clay appears to have been sourced locally, and indeed the titania content (c. $1 \mathrm{wt} \%, \mathrm{SD}=0.2$ ) of the analysed ceramic samples, and the presence of naturally occurring ilmenitemagnetite grains within the tuyère fabrics, corroborates the use of local clays.

Several samples of smelting slag collected from surface scatters from two sites in the North Pare highlands by Dr Edwinus Lyaya in 2010 - Shimbomu and Sungu-chu (Fig. 1) - were also made available for microscopic analysis and EPMA by L. Iles at the University of Arizona. On the whole, they bore some striking similarities to the samples from the lowland smelting sites: the samples were dominated by ulvöspinels, with ilmenite also frequent, indicating the titania-rich nature of these samples. Residual magnetite grains - some partly reduced to iron metalwere present at the edges of some of the samples. Together, this implies the use of similar magnetiteilmenite ore sands as used in the lowland smelts. However, one notable difference was in the size of the crystal phases present, which were significantly finer in the upland smelting slag samples, and which relate to rapid cooling of the slag after it was formed. Consistent with this is the presence of distinct linear changes in phase size (Fig. 15a, b), which might be suggestive of slag tapping, with the slag cooling rapidly outside of the furnace structure. Flows of slag are also visible macroscopically and microscopically in slag samples from a lowland site on the eastern side of the mountains (Kigombe, Figs. 1 and 16). A further anomaly is the chemical composition of the Kigombe slag, which contains very little titania and few ulvöspinels in the microstructure. This may suggest that a different source of ore was used for these smelts, reflecting the strong variability of bedrock across the Pare Mountains (Heckmann 2011, p. 12), although it might also suggest that these are unusual examples of smithing slags. A further possibility is that these are examples of refining slags - a secondary processing stage between smelting and smithing, which can result in flows of slag (Lyaya et al. 2012). With no

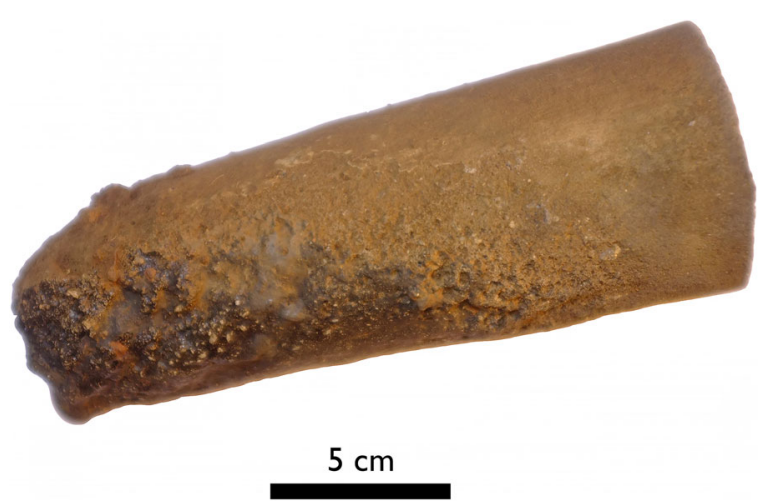

Fig. 14 Tuyère from Mwanga G. (photo: L. Iles) 

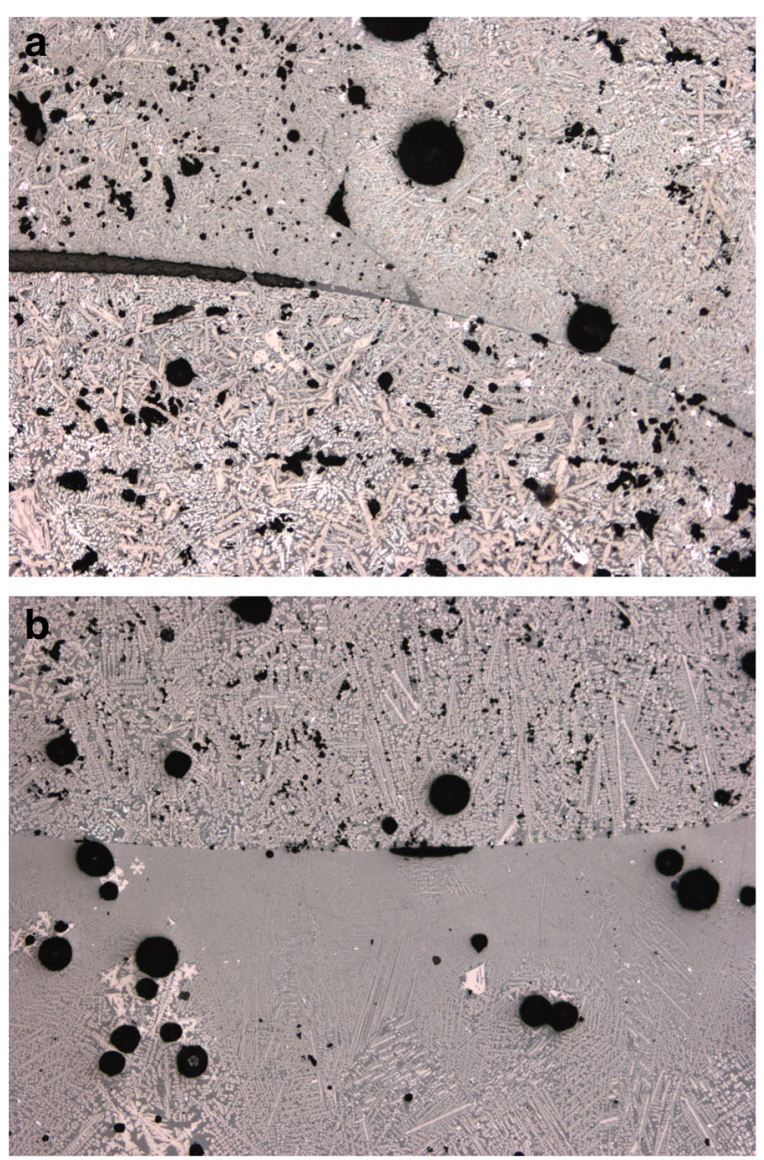

Fig. 15 a Flow structure in slag sample from Sungu-chu. b Flow structure in slag sample from Shimbomu. Image widths approximately $2.5 \mathrm{~mm}$. (photos: L. Iles)

contextual or chronological information about these samples, it is challenging to interpret the variation that they demonstrate. However, they do indicate smelting technology that was markedly different in approachin terms of furnace design and/or raw material usewhich deserves further investigation.

\section{Discussion}

With access to a considerably broadened archaeological and archaeometallurgical database, as well as historical sources, this research contributes in several ways to building a more complete understanding of the organisation of the iron industries of North Pare. In particular, the surface collections of possible highland smelting slag as well as anecdotal accounts of earlier periods of smelting at the highland smithing site of Ngalanga (Musa Mshana, Ngalanga, pers. comm. 2014) raise the possibility that the distinction between upland smithing and lowland smelting previously emphasised by historians and anthropologists might be a relatively recent historical development. If this was indeed the case, this shift may have occurred in response to various factors. One might have been an increased desire or need to situate large-scale ritualised activity - as is often associated with smelting - away from crop growing areas following a period of agricultural intensification. This could potentially coincide with the establishment of terracing and irrigation systems in the highlands, which date as far back as the sixteenth century AD (Stump 2010) and may have become more pronounced with the agricultural intensification that is assumed to have accompanied the growth of the caravan trade from the nineteenth century (Håkansson 2008b).

Unfortunately, there are no first-hand accounts of the working practices of Pare smelters that extend beyond technical descriptions, although ritual behaviour associated with smelting activity has been well-documented elsewhere in the wider region (e.g., Brock 1965; Barndon 2004) and taboos associated with iron production have been noted in North Pare (Sheridan 2001, pp. $113,125)$. If heavily ritualised, smelting - which generally demands a larger spatial footprint than smithing may consequently have been restricted to Pare's lowland areas in the latter half of the second millennium AD. These areas tend to be subject to hotter and drier conditions and more extreme seasons, thus making these areas less suitable for cultivation. Mwanga, for example, sits in the rain shadow to the west of the Pare hills (Sheridan 2009), making it less preferable for farming than other Pare regions. This would have left the highland areas - characterised by more amenable conditions (pleasant climate, reliable rainfall and perennially available water), defensible positions and reduced occurrences of diseases such as malaria (Håkansson 1995) - free to be exploited for living and farming. Indeed, Odner (1971, p. 90) noted that occupation of the plains was reputedly a recent phenomenon.

Nevertheless, alternative cultural factors - as yet not fully understood - may have influenced the spatial separation between smelters and non-smelters. Contemplating the foothills below Vudee, Baumann considered that "the outlets of the streams in the plain would certainly provide enough arable land for corn, but the Vudeepeople dare not go down there. The streams are 
Fig. 16 Flow structure in slag sample from Kigombe. (photo: L. Iles)

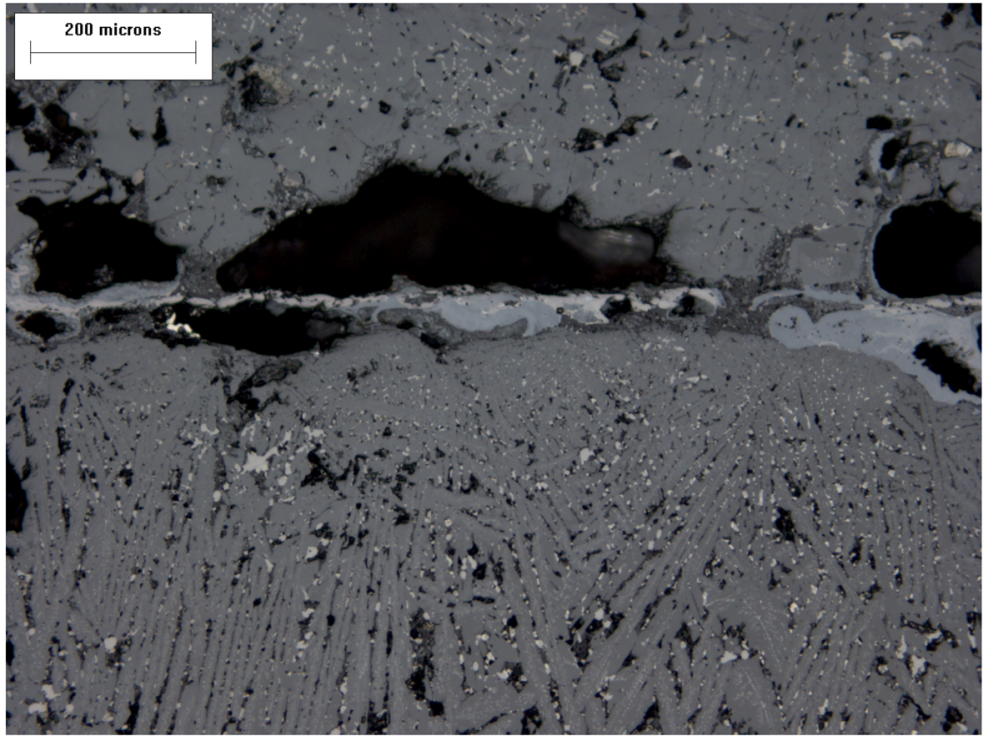

particularly rich in iron, and the smoke of the fires of small smelting furnaces are everywhere" ("An den Austritts-stellen der Bäche in die Ebene würde sich freilich genügend Ackerboden für Maisbau finden, doch wagen sich die Wudeh-leute nicht dort hinab. Ihre Bäche sind besonders eisenhaltig, und allerorts rauchen die Feuer der kleinen Schmelzwerke") (Baumann 1891, p. 208). Butu was also noted as an area of rich agricultural potential (Sheridan 2001, pp. 101, 218), yet the plains to the east and west of the mountains were seen until recently as dangerous places to live due to wild animals and the threat of raiding (Odner 1971). It is possible that intermittent smelting - requiring a less permanent presence than agriculture-was a more appropriate activity in these areas. Certainly, the key raw materials required for smelting - ores and fuel-are seemingly available in both lowland and upland areas, although cultural limitations on their accessibility (such as sacred forests and accompanying restrictions on fuel procurement) may have determined whether these resources were useable.

\section{Building a Chronology of the Iron Technologies of North Pare}

The review of previous work on Pare's precolonial iron industry highlighted a significant lack of understanding of the chronology of both iron production and working in this region. Ideally, a much larger spectrum of sealed furnace contexts would have been dated during this research, but finding well-preserved furnace bases in the Pare mountains - where intensive agriculture and erosion activity continually remodel the landscapehas proved difficult, even with the use of magnetic geophysical survey. The unusual paucity of diagnostic ceramics at most of the recently excavated sites, with the exception of Mwanga $G$, has not aided attempts to determine a secure chronology.

The radiocarbon dates currently available do not establish a clear chronological overlap between smelting activity at the excavated lowland smelting sites and the upland smithing site of Ngalanga. However, this does not preclude the possibility of contemporaneous activity. Based solely on the existing dates, the investigated lowland smelting sites - on both the eastern and western flanks of the mountains - date to within the first few centuries of the second millennium AD (c. 10001250 cal. AD), with Mwanga $C$ and Mwanga G potentially in operation until the mid-second millennium AD. This contrasts with the dates for smithing at Ngalanga, which cluster in the second half of the second millennium $\mathrm{AD}$, limited in their precision by the flattened calibration curve in this period. However, it is still possible to suggest some extent of continuity of practice between these traditions. The smelting of local ore sands - documented by early European travellers - continued at least until the end of the nineteenth century. The use of locally produced bloomery iron at the smithing site of Ngalanga after AD 1500 is also in evidence - probably deriving from several sources in North Pare (potentially 
both lowland and highland smelting sites) and possibly also South Pare. At present, there are no archaeological data regarding the shift to smithing using imported iron, but it is presumed that this did not occur until well into the early twentieth century, and the establishment of the Tanga-Moshi railway line.

\section{Erosion and Iron Production in North Pare}

Geoarchaeological research undertaken under the auspices of the HEEAL project (Lane 2010) between 2007 and 2011 highlighted a number of significant changes in land use practices across North Pare commencing with the advent of agriculture two thousand years ago, and a Pare-wide pattern of intensifying soil erosion since about AD 1500 (Heckmann 2011, 2014; Heckmann et al. 2014). These soil erosion stages are likely attributable to a combination of anthropogenic and climatic (e.g., Little Ice Age) drivers. Since the late nineteenth century, it has commonly been assumed that industrialscale iron smelting and smithing was a major stimulus (Schmidt 1989; Håkansson 2008a). The greater prosperity of the area, owing in part to the exchange of iron products and the accumulation of cattle herds, may have further triggered an intensification of agricultural production. This would have been facilitated by a ready supply of hoes, axes and other iron tools for farm work, resulting in increased clearance of vegetation and reduced periods of fallow, both of which could have been contributory factors to initiating and/or intensifying soil erosion. Increased demand for agricultural products on the part of trade caravans passing through the Pangani basin from the mid-nineteenth century onwards, and the opportunities for exchange that the caravans presented, may have also stimulated surplus agricultural production around this time (Håkannson 2008b; however, cf. Biginagwa 2012), and hence further soil erosion and environmental degradation. Assessing the relative contribution of these different anthropogenic factors, alongside those of possible climatic drivers, remains challenging. Nonetheless, landscape-scale geoarchaeological studies indicate that overall, soil erosion patterns in both the Pare highlands and lowlands reveal similar developments closely tied to the history of human settlement (Heckmann 2011, 2014; Heckmann et al. 2014).

In the highlands, local soil erosion commenced in the last centuries $\mathrm{BC}$, and the recovery of potsherds indicative of concurrent settlement suggests that early agriculture was a central agent of forest clearance, surface instability and changing hydrological conditions such as swamp establishment. In the mid-first millennium AD, pollen records indicate that the submontane forest vegetation had already been cleared (Heckmann et al. 2014). In the first part of the second millennium AD, runoff-based erosion of subsoils documented in colluvial sediments at Mrongo and Usumbwe near Ngalanga mark the onset of widespread accelerated soil erosion (Heckmann 2011, 2014). The smithing hearths excavated at Ngalanga were cut into such an eroded land surface, and their post-AD 1500 radiocarbon dates suggest that iron working at Ngalanga took place in an already strongly degraded environment.

Similar to the anthropogenic environmental change documented in the highlands, the onset of sediment accumulation in the Kisangara depression around Mwanga started during the last centuries BC (Heckmann, unpublished data). The sedimentary cover extends not only along the main channel but also along small tributaries, indicating that the source of sediments was not limited to the highland areas, but also included foothills and pediments. This early and prolonged phase of landscape instability cannot currently be explained by iron production activity, as the oldest documented smelting sites at Mwanga date to the beginning of the second millennium AD. Similar to the findings at Ngalanga, the furnaces at Mwanga A to D were established on an already eroded land surface, which confirms widespread erosion of the upper pediments prior to the smelting activity documented here. A distinct layer of alluvial sands in the Kisangara depression marks a local erosion episode around AD 1250. Broadly contemporary with the iron smelting activities around Mwanga, this erosion pulse could be related to widespread soil erosion and forest clearance on the lower pediments and foothills.

Micromorphological analysis of undisturbed soil samples collected immediately below and above an excavated furnace at Mwanga $\mathrm{C}$ suggests that prior to the establishment of smelting at the site, there was little evidence of cultivation. However, redeposited clay loam in the soil thin section from above the furnace displayed evidence of increased organic residues, root material (including straw, Fig. 17) and a well-developed channel microstructure that suggests cultivation had occurred at the site at some point after iron production had ceased. If agriculture had occurred at Mwanga prior to the iron smelting activity, evidence for it probably would have been eroded. Nevertheless, the micromorphological 


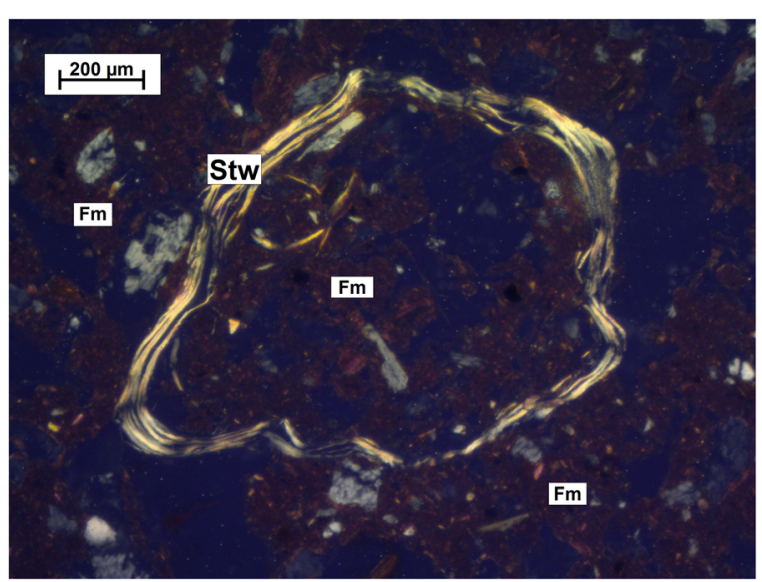

Fig. 17 Micromorphological image of straw-like material (Stw) sitting within the fine matrix (Fm) of soil from Mwanga C. (photo: C. Lang)

analysis does suggest that during later periods, agriculture did take place in the lowlands.

The archaeological exploration of the iron working sites described above has illustrated the intensity of soil erosion processes at work in these areas. It is apparent that erosion has been, and continues to be, substantial across North Pare, both in the lowlands and the highlands, and these sites appear to have been significantly damaged since they were first identified. This is illustrated by the transient nature of some archaeological features identified during episodes of survey - such as the house foundations identified by Odner at Mwanga A (since disappeared), the furnace base identified at Butu I in 2009 (of which no trace was left 4 years later) and a furnace at Mwanga C (preserved only due to the build-up of deposits around a plant pedestal, Fig. 7b). The simple construction processes used for the furnaces described by Baumann (1891), Kersten (1869) and Kotz (1922) may not have facilitated their long-term survival in the archaeological record given a high intensity of erosion. Furthermore, topsoil and archaeological deposits are consistently thin throughout North Pare, whether in the highlands or the lowlands, demonstrating that this erosion has continued until recently.

In terms of archaeological reconstruction, this widespread soil erosion presents a challenge. If the land surfaces prior to AD 1500 are eroded, it becomes difficult to find in situ archaeological sites on the highland slopes. Archaeological remains dating to before AD 1500 may have been eroded and incorporated into the colluvial valley fills or locally redeposited within small depressions along the slopes. As soil erosion continued since AD 1500, the same would apply for younger archaeological sites.

\section{Conclusion}

Heckmann etal. (2014) attributed the early and prolonged deforestation to the combined effects of clearance through the spread of agriculture and the charcoal demands of iron working technologies. Whereas documentary accounts emphasise the importance of iron smelting in nineteenth-century Pare, the (geo-)archaeological evidence in Pare for iron working during the early centuries $\mathrm{AD}$ is only circumstantial. The stratigraphic and chronological relationship between the soil erosion and the documented evidence for smithing and smelting suggests that erosion processes were well established in North Pare prior to an intensification of smelting and smithing activity. It is also clear that smelting and smithing continued throughout - and despite - this erosion activity (see similar evidence for central Tanzania in Mapunda 2003, 2013). The intensification of iron production (and metal production more generally) has often been attributed with triggering deforestation and thus erosion in many areas of the world (Iles 2016), northern Tanzania included (e.g., Schmidt 1988), or otherwise having localised impacts on regional vegetation structures (e.g., Lupo et al. 2015). However, the geoarchaeological and archaeological evidence from North Pare suggests that iron production is unlikely to be the sole contributor in this instance, with climate and agriculture also playing a role (see also Finch et al. 2017 who document a rise in lowland forest taxaincluding those preferred for smelting and smithing [Lyaya 2013] — in South Pare around the end of the thirteenth century $\mathrm{AD}$ ). A parallel study that seeks to quantify the fuel required to support smelting activity in North Pare, and the implications that this has for environmental impact of iron production in Pare, is to be published elsewhere (Iles in preparation a), and supports this proposition that iron production was not the determining factor of local vegetation change.

It is possible that sampling bias, driven by a nonsystematic survey approach, has skewed the selection of sites that have been located and studied as part of this research. Erosion processes may have destroyed or covered sites that could contribute key data to the emerging picture of Pare's industrial past. The potential loss of evidence for earlier iron working phases in particular, limits the inferences that can be made regarding the 
relationship between iron production and landscape change. Although soil erosion predates the iron working sites documented here, the lack of data does not intrinsically rule out the possibility of earlier iron production. Nevertheless, it is clear from the newly available archaeological evidence generated as part of this research programme that iron metallurgy was an important cornerstone of socio-economic life in the Pare Mountains from at least as early as the first half of the second millennium AD, and possibly earlier. During this period, iron was regularly produced from local titania-rich magnetite sands which continued as a sustainable and flourishing industry until the start of the twentieth century, alongside a successful smithing industry concentrated predominantly in the highlands.

Key priorities for future research should be to more comprehensively document metallurgical activity in the highland areas of North Pare, incorporating targeted survey to identify and investigate highland smelting sites as well as a broader range of upland smithing sites. This would also enable a more detailed exploration of variations in furnace construction as suggested by the historical and archaeological records. An archaeometallurgical investigation of smelting and smithing in neighbouring South Pare-perhaps focusing on Vudee since it was mentioned as an iron working area by several nineteenth-century travellers-would also enable a more fully developed discussion of the economics of iron production in the Pare Mountains as a whole. Finally, a focus on fuel wood choice, the spatial distribution of the different species preferred for metallurgical processes and the systematic identification of wood charcoal recovered from smelting and smithing contents, coupled with ethnohistorical research on indigenous ecological knowledge relating to iron production would be highly beneficial in building a more refined picture of the relationship between past iron production activity and its environmental impact.

Acknowledgements This research has been carried out in receipt of funding from the European Union Sixth and Seventh Framework Programmes. The research by MH, DS and PL was undertaken as part of the Historical Ecologies of East African Landscapes project (2007-11) hosted by the University of York and funded by a Marie-Curie Excellence award (MEXT-CT-2006042704) to PL. LI's research formed part of her EnvIron project (2013-15) funded by a Marie-Curie International Outgoing Fellowship (FP7-IOF-2012-331419), mentored by PL and David Killick, and co-hosted by the University of York and the University of Arizona. The contents reflect only the authors' views and not the views of the European Commission. The authors would like to acknowledge support from the British Institute in Eastern Africa (BIEA), the University of York and the University of Arizona, and to thank all project participants who contributed in the field, in particular Ahadi Msuya and his family. Especial thanks are also due to Michael Sheridan (Middlebury College) for generously sharing information he has collected over the years regarding iron working in the Pare Mountains; Jana Jiroušková and Hana Procházková (Náprstek Museum, Prague) for information concerning the ethnographic collections made by Martin Lány and Hans Fuchs, and for providing the photographs reproduced in Fig. 3; Monika Baumanova (Uppsala University) for translating material from Czech; Bente Odner for sharing Knut Odner's excavation archives and Else Kleppe for facilitating this; and Robert Soper and the BIEA for permission to reproduce Fig. 4. We are grateful to two anonymous reviewers for their insightful comments on an earlier draft of this paper.

Funding This study was funded by a Marie-Curie International Outgoing Fellowship (FP7-IOF-2012-331419) and a Marie-Curie Excellence award (MEXT-CT-2006-042704).

\section{Compliance with Ethical Standards}

Conflict of Interest The authors declare that they have no conflict of interest.

Open Access This article is distributed under the terms of the Creative Commons Attribution 4.0 International License (http:// creativecommons.org/licenses/by/4.0/), which permits unrestricted use, distribution, and reproduction in any medium, provided you give appropriate credit to the original author(s) and the source, provide a link to the Creative Commons license, and indicate if changes were made.

\section{References}

Barndon, R. (2004). A discussion of magic and medicines in East African iron working: Actors and artefacts in technology. Norwegian Archaeological Review, 37, 21-40.

Baumann, O. (1891). Usambara und seine Nachbargebiete. Berlin: Dietrich Reimer.

Biginagwa, T. (2012). Historical archaeology of the nineteenthcentury caravan trade in northeastern Tanzania: a zooarchaeological perspective. $\mathrm{PhD}$ thesis, University of York.

Brock, B. (1965). Iron working amongst the Nyiha of southwestern Tanganyika. The South African Archaeological Bulletin, 20, 97-100.

Bronk Ramsey, C. (2009). Bayesian analysis of radiocarbon dates. Radiocarbon, 51, 337-360.

Brown, J. (1995). Traditional metal working in Kenya. Oxford: Oxbow.

Chirikure, S. (2007). Metals in society: Iron production and its position in Iron Age communities of southern Africa. Journal of Social Archaeology, 7, 72-100. 
Cline, W. (1937). Mining and metallurgy in Negro Africa. Wisconsin: George Banta.

Finch, J., Marchant, R., \& Courtney-Mustaphi, C. (2017). Ecosystem change in the south Pare mountain bloc. Eastern Arc Mountains of Tanzania. The Holocene, 27, 796-810.

Fosbrooke, H. (1954). Further light on rock engravings in northern Tanzania. Man, 54, 101-102.

Fosbrooke, H. (1957). Early Iron Age sites in Tanganyika relative to traditional history. In J. Desmond \& S. Cole (Eds.), Third Pan-African congress on prehistory, Livingstone, 1955 (pp. 318-325). London: Chatto \& Windus.

Håkansson, N. T. (1995). Irrigation, population pressure, and exchange in precolonial Pare, Tanzania. Research in Economic Anthropology, 16, 297-323.

Håkansson, N. T. (2008a). The decentralized landscape: Regional wealth and the expansion of production in northern Tanzania before the eve of colonialism. In L. Cliggett \& C. Pool (Eds.), Economies and the transformation of landscape (pp. 239265). Lanham: Alta Mira Press.

Håkansson, N. T. (2008b). Regional political ecology and intensive cultivation in pre-colonial and colonial South Pare. Tanzania. The International Journal of African Historical Studies, 41, 433-459.

Heckmann, M. (2011). Soil erosion history and past human land use in the North Pare Mountains. A geoarchaeological study of slope deposits in NE Tanzania. PhD thesis, University of York.

Heckmann, M. (2014). Farmers, smelters and caravans: Two thousand years of land use and soil erosion in North Pare, NE Tanzania. Catena, 113, 187-201.

Heckmann, M., Muiruri, V., Boom, A., \& Marchant, R. (2014). Human-environment interactions in an agricultural landscape: A 1400-yr sediment and pollen record from North Pare, NE Tanzania. Palaeogeography, Palaeoclimatology, Palaeoecology, 406, 49-61.

Hogg, A. G., Hua, Q., Blackwell, P. G., Niu, M., Buck, C. E., Guilderson, T. P., Heaton, T. J., Palmer, J. G., Reimer, P. J., Reimer, R. W., Turney, C. S. M., \& Zimmerman, S. R. H. (2013). SHCal13 Southern Hemisphere Calibration, 0-50, 000 Years cal BP. Radiocarbon, 55, 1889-1903.

Holy, L. (1957). Získávání a zpracovávání železa u východoafrických Bantu. Československá Ethnografie, 5(273-288), 348-367.

Holy, L. (1958). Získávání a zpracovávání železa u východoafrických Bantu. Československá Ethnografie, 6, 144-162 270-280, 381-395.

Holy, L. (1959). Die Eisenindustrie der Pare-Gweno. In T. Bodrogi \& L. Boglár (Eds.), Opuscula ethnologica memoriaw Ludovici Biró Sacra (pp. 405-424). Budapest: Akadémia Kiadó.

Ige, A. (2013). Yoruba iron metallurgy: Raw materials, routine and rituals. In J. Humphris \& T. Rehren (Eds.), The world of iron (pp. 29-34). London: Archetype.

Ige, A., \& Rehren, T. (2003). Black sand and iron stone: Iron smelting in Modakeke, Ife, south western Nigeria. IAMS, 22, $19-21$.

Iles, L. (2013). Applying ethnographic presents to archaeological pasts: The relevance of memories of iron production in western Uganda. In J. Humphris \& T. Rehren (Eds.), The world of iron (pp. 281-287). London: Archetype.
Iles, L. (2016). The role of metallurgy in transforming global forests. Journal of Archaeological Method and Theory. https://doi.org/10.1007/s10816-015-9266-7.

Iles, L., \& Martinón-Torres, M. (2009). Pastoralist iron production on the Laikipia Plateau, Kenya: Wider implications for archaeometallurgical studies. Journal of Archaeological Science, 36, 2314-2326.

Illife, J. (1979). A modern history of Tanganyika. Cambridge: Cambridge University Press.

Jiroušková, J. (2010). Two men at the foot of Kilimanjaro: African collections of Martin Lány and Hans Fuchs. Prague: Národní Muzeum, Editio Monographica Musei Nationalis Pragae 8.

Kaoneka, A. R. S., \& Solberg, B. (1994). Forestry related land use in the west Usambara Mountains. Tanzania. Agriculture, Ecosystems and Environment, 49, 207-215.

Kersten, O. (1869). Baron Carl Claus von der Decken's reisen in Ost-Afrika in den jahren 1862 bis 1865 (Vol. II). Graz: Akademische Druck und Verlagsanstalt.

Killick, D., \& Miller, D. (2014). Smelting of magnetite and magnetite-ilmenite iron ores in the northern Lowveld, South Africa, ca. $1000 \mathrm{CE}$ to ca. $1880 \mathrm{CE}$. Journal of Archaeological Science, 43, 239-255.

Kimambo, I. (1968). The Pare. In A. Roberts (Ed.), Tanzania before 1900 (pp. 16-31). Nairobi: East African Publishing House.

Kimambo, I. (1969). A political history of the Pare of Tanzania c. 1500-1900. Nairobi: East African Publishing House.

Kimambo, I. N. (1996). Environmental control and hunger in the mountains and plains of northern Tanzania. In G. Maddox, J. Giblin, \& I. N. Kimambo (Eds.), Custodians of the land: Ecology and culture in the history of Tanzania (pp. 71-95). London: James Currey.

Kotz, E. (1922). Im Banne der Furcht: Sitten und Gebräuche der Wapare in Ostafrika. Hamburg: Advent-Verlag.

Lane, P. (2010). Developing landscape historical ecologies in eastern Africa: An outline of current research and potential future directions. African Studies, 69, 299-322.

Lupo, K., Schmitt, D., Kiahtipes, C., Ndanga, J., Young, D., \& Simiti, B. (2015). On intensive Late Holocene iron mining and production in the northern Congo Basin and the environmental consequences associated with metallurgy in Central Africa. PLoS One, 10(7), e0132632.

Lyaya, E. (2013). Use of charcoal species for ironworking in Tanzania. In J. Humphris \& T. Rehren (Eds.), The world of iron (pp. 444-453). London: Archetype.

Lyaya, E., Mapunda, B., \& Rehren, T. (2012). The bloom refining technology in Ufipa, Tanzania (1850-1950). In C. RobionBrunner \& B. Martinelli (Eds.), Métallurgie du fer et Sociétés africaines: Bilans et nouveaux paradigmes dans la recherché anthropologique et archaeologique (pp. 195-207). BAR International Series (p. 2395). Oxford: BAR Publishing.

Maghimbi, S. (1994). Pre-capitalist modes of production in Tanzania: Reference to modes of production in the old Ugweno state of north-eastern Tanzania. UTAFITI (New Series), 1, 20-35.

Mapunda, B. (2003). Iron technology and deforestation: Myths and realities. AFRAS. In University of Sussex.

Mapunda, B. (2013). Ironworking and deforestation in precolonial Africa: The case of Kondoa Irangi, central Tanzania. UTAFITI, 10(2), 65-89. 
Mbaga-Semgalawe, Z., \& Folmer, H. (2000). Household adoption behaviour of soil conservation: The case of North Pare and West Usambara Mountains of Tanzania. Land Use Policy, 17, 321-336.

Meyer, H. (1891). Across East African glaciers: An account of the first ascent of Kilimanjaro [translated by E. Calder]. London: George Philip \& Son.

Mtetwa, E., Maposa, Y. C., Manyanga, M., \& Chirikure, S. (2017). When the smith is a woman: Innovation, improvisation and ambiguity in the organisation of African iron metallurgy. In M. Manyanga \& S. Chirikure (Eds.), Archives, objects, places and landscapes: Multidisciplinary approaches to decolonised Zimbabwean pasts (pp. 295-318). Bamenda: Langaa RPCIG, Bamenda.

Newmark, W. D. (1998). Forest area, fragmentation, and loss in the Eastern Arc Mountains: Implications for the conservation of biological diversity. Journal of East African Natural History, 87, 29-36.

Odner, K. (1971). Usangi hospital and other archaeological sites in the north Pare Mountains, north-eastern Tanzania. Azania, 6, 89-130.

Pleiner, R. (2000). Iron in archaeology: The European bloomery smelters. Prague: Archeologigký Ustav Av Čr.

Raymaekers, J., \& van Noten, F. (1986). Early iron furnaces with 'bricks' in Rwanda: Complementary evidence from Mutwarubona. Azania, 21, 65-84.

Reimer, P. J., Bard, E., Bayliss, A., Beck, J. W., Blackwell, P. G., Bronk Ramsey, C., Grootes, P. M., Guilderson, T. P., Haflidason, H., Hajdas, I., HattŽ, C., Heaton, T. J., Hoffmann, D. L., Hogg, A. G., Hughen, K. A., Kaiser, K. F., Kromer, B., Manning, S. W., Niu, M., Reimer, R. W., Richards, D. A., Scott, E. M., Southon, J. R., Staff, R. A, Turney, C. S. M., \& van der Plicht, J. (2013). IntCal13 and Marine13 radiocarbon age calibration curves $0-50,000$ years cal BP. Radiocarbon, 55, 1869-1887.
Routledge, W., \& Routledge, K. (1910). With a prehistoric people: The Akikuyu of British East Africa. London: Edward Arnold.

Schmidt, P. (1988). Eastern expressions of the "Mwitu" tradition: Early Iron Age industry of the Usambara Mountains, Tanzania. Nyame Akuma, 30, 36-37.

Schmidt, P. (1989). Early exploitation and settlement in the Usambara Mountains. In A. Hamilton \& R. Bensted-Smith (Eds.), Forest conservation in the east Usambara Mountains, Tanzania (pp. 75-78). Gland: IUCN.

Sheridan, M. (2001). Cooling the land: The political ecology of the North Pare Mountains, Tanzania. PhD thesis, Boston University.

Sheridan, M. (2009). The environmental and social history of African sacred groves: A Tanzanian case study. African Studies Review, 52, 73-98.

Soper, R. (1967). Iron Age sites in north-eastern Tanzania. Azania, 2, 19-36.

Soper, R. (1976). Archaeological sites in the Chyulu Hills. Kenya. Azania, 11, 83-116.

Stahl, K. (1964). History of the Chagga people of Kilimanjaro. London: Mouton \& Co..

Stump, D. (2010). Ancient and backward or long-lived and sustainable? The role of the past in debates concerning rural livelihoods and resource conservation in eastern Africa. World Development, 38, 1251-1262.

Sutton, J. (1972). Iron working in Tanzania. Kale: The magazine of the University Branch of the Historical Association of Tanzania, 1, 34-48.

Walz, J. (2010). Routes to a regional past: an archaeology of the lower Pangani (Ruvu) basin, Tanzania, 500-1900 C. E. PhD thesis, University of Florida.

Walz, J. (2017). Inland connectivity in ancient Tanzania. Islamic Africa, 8, 217-227. 